\title{
From Systemic Banking Crises to Fiscal Costs: Risk Factors
}




\section{WP/15/166}

\section{IMF Working Paper}

\section{From Systemic Banking Crises to Fiscal Costs: Risk Factors}

by David Amaglobeli, Nicolas End, Mariusz Jarmuzek, and Geremia Palomba

IMF Working Papers describe research in progress by the author(s) and are published to elicit comments and to encourage debate. The views expressed in IMF Working Papers are those of the author(s) and do not necessarily represent the views of the IMF, its Executive Board, or IMF management.
I N T E R N A T I O N A L
$M O N E T A R Y$
F U N D 


\title{
IMF Working Paper
}

Fiscal Affairs Department

\section{From Systemic Banking Crises to Fiscal Costs: Risk Factors}

\section{Prepared by David Amaglobeli, Nicolas End, Mariusz Jarmuzek, and Geremia Palomba ${ }^{1}$}

Authorized for distribution by Bernardin Akitoby

July 2015

\section{IMF Working Papers describe research in progress by the author(s) and are published to elicit comments and to encourage debate. The views expressed in IMF Working Papers are those of the author(s) and do not necessarily represent the views of the IMF, its Executive Board, or IMF management.}

\begin{abstract}
This paper examines the risk factors associated with fiscal costs of systemic banking crises using cross-country data. We differentiate between immediate direct fiscal costs of government intervention (e.g., recapitalization and asset purchases) and overall fiscal costs of banking crises as proxied by changes in the public debt-to-GDP ratio. We find that both direct and overall fiscal costs of banking crises are high when countries enter the crisis with large banking sectors that rely on external funding, have leveraged non-financial private sectors, and use guarantees on bank liabilities during the crisis. The better quality of banking supervision and the higher coverage of deposit insurance help, however, alleviate the direct fiscal costs. We also identify a possible policy trade-off: costly short-term interventions are not necessarily associated with larger increases in public debt, supporting the thesis that immediate intervention may be actually cost-effective over time.
\end{abstract}

JEL Classification Numbers: E50; E60; G20

Keywords: Banking crisis, financial crisis, fiscal costs, contingent liabilities

Authors' email addresses: DAmaglobeli@,imf.org, NEnd@,imf.org, MJarmuzek@,imf.org, GPalomba@imf.org

\footnotetext{
${ }^{1}$ The authors thank, without implicating, Vitor Gaspar, Gilbert Terrier, Bernardin Akitoby, Frederic Lambert, Priscilla Muthoora, Marek Raczko, Fabian Valencia, Daniel Hardy, Mario Mansilla, Alberto Martin, Nina Budina, Borja Gracia, Iva Petrova, Sergei Saksonovs, Said Bakhache, Heiko Hesse, Antonio Bassanetti, and participants at IMF seminars for useful discussions, comments, and suggestions. Malin Hu and Carolina Correa Caro provided outstanding research assistance. All the remaining errors are our own.
} 
Contents

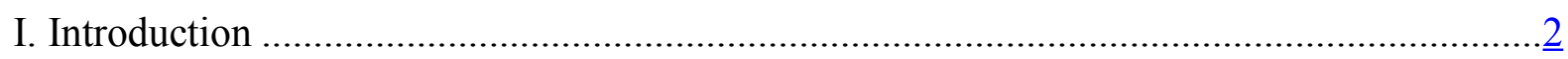

II. Conceptual Framework ............................................................................................

A. Defining Fiscal Costs of Banking Crises ................................................................

B. Explaining Systemic Banking Crises and Fiscal Costs .............................................

III. Fiscal Costs of Banking Crises ...............................................................................

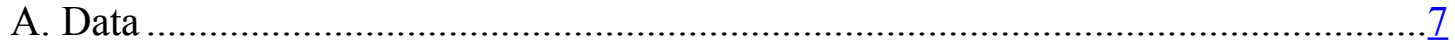

B. Three Decades of Systemic Banking Crises: Stylized Facts.....................................

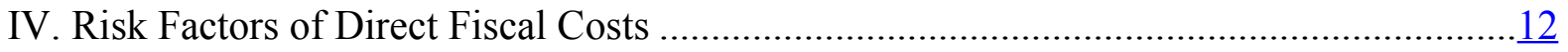

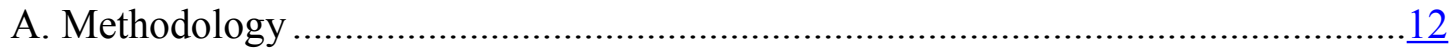

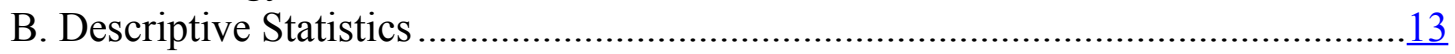

C. Econometric Analysis ...............................................................................16

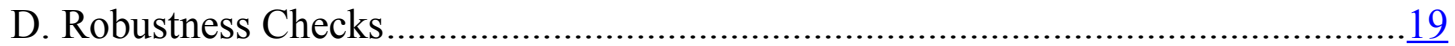

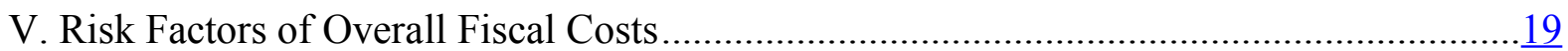

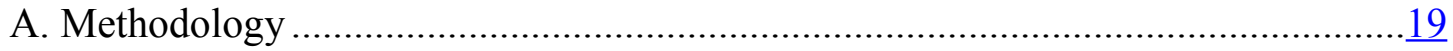

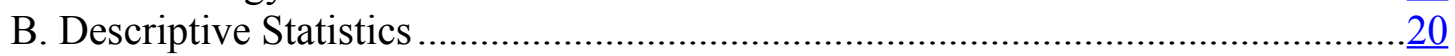

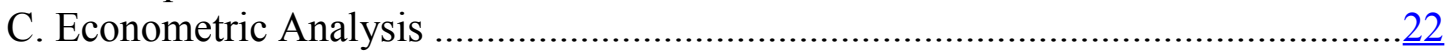

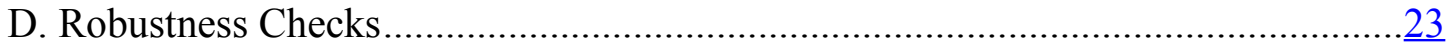

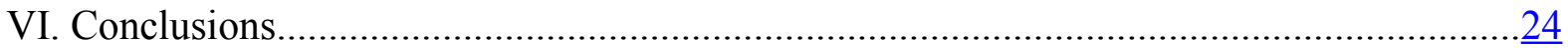

\section{Tables}

1. Direct Fiscal Costs across Selected Vulnerability Indicators for Recent Banking Crisis, 2007-11. 17

2. Overall Fiscal Costs across Selected Vulnerability Indicators ...................................................... 21

\section{Figures}

1. From Banking Crises and Public Finances: Main Channels................................................

2. Fiscal Costs During Selected Banking Crises.............................................................

3. Fiscal Costs Across Different Waves of Banking Crises..................................................11

4. Recovery Rates Across Selected Banking Crises .........................................................11

5. Public Debt Increase and Direct Fiscal Costs of Banking Crises, 1970-2011 …................12

6. Average Direct Fiscal Costs, Cross-border Interconnectedness, and Size and Leverage of the Banking and Non-Banking Sectors...................................................13

7. Average Direct Fiscal Costs and Institutions.....................................................................14

8. Average Direct Fiscal Costs and Crisis Policy Response: Containment and

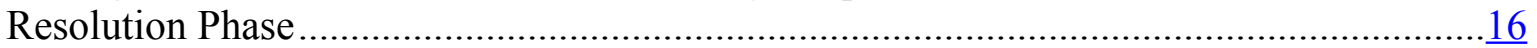

9. Average Overall Fiscal Costs and Policy Responses....................................................20

10. Overall Fiscal Costs and Precrisis Level of Debt-to-GDP ................................................22

\section{Boxes}

1. Recording Direct Fiscal Costs of Banking Crises Under the Government Financial Statistics Manual (GFSM 2001)... 


\section{Appendix Tables}

A1a. Basic Model: Conditional Correlations of Direct Fiscal Costs .$\underline{26}$

A1b. Basic Model: Conditional Correlations of Direct Fiscal Costs ...................................27

A2. Extended Model: Conditional Correlations of Direct Fiscal Costs...............................28

A3. Extended Model: Conditional Correlations of Direct Fiscal Costs

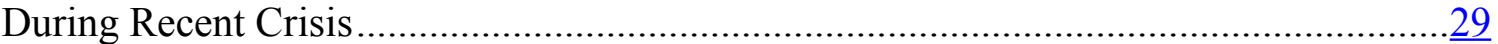

A4. Extended Model for Direct Fiscal Costs: Accounting for NPLs .................................. $\underline{30}$

A5. Extended Model for Direct Fiscal Costs: GMM and Reverse Causality ......................... 31

A6. Basic Model: Conditional Correlations of Overall Fiscal Costs ................................... $\underline{32}$

A7. Extended Model: Conditional Correlations of Overall Fiscal Costs............................... $\underline{33}$

A8. Extended Model for Overall Fiscal Costs: Accounting for NPLs

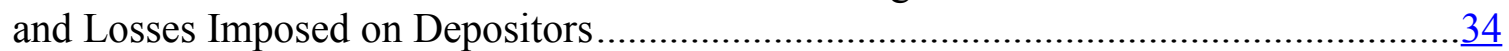

A9. Extended Model for Overall Fiscal Costs: GMM and Reverse Causality ....................... $\underline{35}$

A10. Data and Data Sources ................................................................................... $\frac{36}{36}$

A11. Systemic Banking Crises and Recent Borderline Crisis Episodes............................... 37

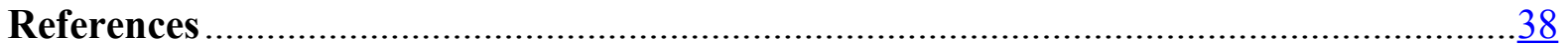




\section{INTRODUCTION}

The recent global financial crisis has renewed policy and research interest in the effects of banking crises on public finances (Laeven and Valencia, 2013; Lane, 2011). Since 2007, there have been 25 new systemic and borderline systemic banking crises, mostly in advanced economies, which have often carried significant fiscal costs. In Iceland and Ireland, for example, the cost of government intervention amounted to more than 40 percent of GDP, and public debt increased by more than 70 percent of GDP in five years (Laeven and Valencia, 2013). The magnitude of these costs is not unusual, compared to past crises.

Systemic banking crises have often resulted in marked deteriorations of public finances, although the impact has varied across countries. The median fiscal cost of direct government intervention during the crises occurred between 1980 and 2011 was about 6 percent of GDP; about one third of crisis episodes recorded direct fiscal costs exceeding 10 percent of GDP. Yet, these direct costs do not capture the full impact of banking crises on public finances; these crises also affect public finances indirectly through crisis-induced recessions and higher borrowing costs (Claessens and others, 2011; IMF, 2015). The overall cost of crises can be better captured by the change in public debt, which includes direct budgetary costs as well as indirect fiscal costs that materialize through the impact of crises on the real economy (as well as any cost recovery). Seen through this prism, the overall costs of banking crises are even larger. The median increase in public debt during the four years that followed crises occurred over 1980-2011 was more than 14 percent of GDP, with the increase exceeding 40 percent of GDP for the 11 most costly crises. ${ }^{2}$ The most recent wave of crises has been no exception, with the median increase in public debt being about 24 percent of GDP; the increase in some countries more than doubled this amount (Deutsche Bank, 2013).

Explaining the magnitude and the cross-country differences in fiscal costs of banking crises remains a challenge. Empirical studies have largely focused on direct fiscal costs and suggest that the determinants of banking crises - such as initial macroeconomic conditions, financial sector characteristics, and countries' institutional features, may help explain observed differences in the severity of the fiscal impact of banking crises (Demirguc-Kunt and Detragiache, 1998). However, most of this empirical literature dates back to late 1990s and early 2000s; as such it does not account for the complexities of modern banking sectors, for example, cross-border linkages. In addition, this literature mainly considers the determinants of fiscal costs separately, not accounting for possible interactions among clusters of risk factors. Finally, the empirical literature has not paid much attention to the overall fiscal costs and the impact of banking crises on public debt. Yet, this is an important policy issue: speedy interventions, although initially costly, may lead to better macroeconomic performance and smaller increases in public debt (IMF, 2015).

This paper provides an empirical analysis of the factors associated with direct fiscal costs of banking crises and public debt dynamics. It combines several recent datasets (i.e., Abiad and

\footnotetext{
${ }^{2}$ In this paper, changes in public debt ratios are measured over [T-1; $\left.\mathrm{T}+4\right]$, where $\mathrm{T}$ is the starting year of the banking crisis.
} 
others, 2008; Laeven and Valencia, 2013; World Bank, 2012), and it examines how specific precrisis banking sector characteristics, countries' regulatory and supervisory frameworks, and policy responses help explain the fiscal costs of crises. Our analysis covers both past and most recent systemic and borderline systemic banking crisis episodes.

This paper addresses some of the limitations of the existing literature. In particular, it departs from previous literature and examines both the direct fiscal costs of banking crises and their overall costs as summarized by debt dynamics. Admittedly, the change in public debt is an imperfect measure of the overall fiscal costs of banking crises, in that it captures variations of debt around a banking crisis and not solely variations due to the crisis. However, it is a more comprehensive measure of fiscal costs. The analysis of both direct and overall fiscal costs has another advantage. It allows the exploration of the impact of government's policy intervention on both direct and overall fiscal costs, thereby highlighting possible empirical trade-offs between the size of initial fiscal outlays and subsequent impacts on fiscal accounts.

The paper shows that the size of fiscal costs of banking crises depends on precrisis banking sector characteristics. Fiscal costs of banking crises are higher in countries where the banking sector is larger, more leveraged, or more reliant on external funding. Costs tend, however, to be lower where banking supervision is stronger and deposit insurance coverage is broader. These findings suggest that recent trends toward more leveraged and internationally integrated banking sectors pose additional risks to public finances, and countries' regulatory and supervisory frameworks can help mitigate these risks. Most of these are salient for both direct and overall fiscal costs, but policy responses have a differential impact. For example, bank guarantees appear to increase both direct and overall fiscal costs; the correlation is less clear-cut though for other policy measures, such as recapitalizations and asset purchases. Even though these short-term measures have initial direct fiscal costs, they do not necessarily add to the overall fiscal cost of crises. These findings suggest a possible tradeoff between costly short-term policy interventions and the overall increase in public debt.

The remainder of the paper is organized as follows. Section II presents the conceptual framework used to analyze the fiscal costs of banking crises, building on the relevant literature on banking crises. Section III presents our dataset and a few stylized facts about fiscal costs of banking crises, and the peculiarities of the recent wave of crises. Sections IV and $\mathrm{V}$ investigate the relation between two types of fiscal costs and initial macroeconomic conditions, and financial sector characteristics and institutions, as well as policy responses. Section VI concludes the paper.

\section{CONCEPTUAL FramewORK}

This section provides definitions of fiscal costs and discusses the main channels through which banking crises affect public finances. 


\section{A. Defining Fiscal Costs of Banking Crises}

The literature traditionally differentiates between direct and indirect channels through which banking crises can affect public finances; each channel carries some form of fiscal costs (Figure 1). ${ }^{3}$

- Direct fiscal costs. These costs result from direct governmental interventions in the banking sector during a crisis. These interventions usually follow the crisis containment phase, during which central banks try to stabilize the banking sector, mainly through liquidity support. Identification of a solvency problem could trigger government interventions, which are implemented mainly through recapitalizations and asset purchases. Governments may also need to compensate depositors, pay off explicit contingent liabilities that materialize (e.g., calls on guarantees), and, if needed, recapitalize the central bank for losses incurred on previously provided liquidity support.

Figure 1. From Banking Crises and Public Finances: Main Channels

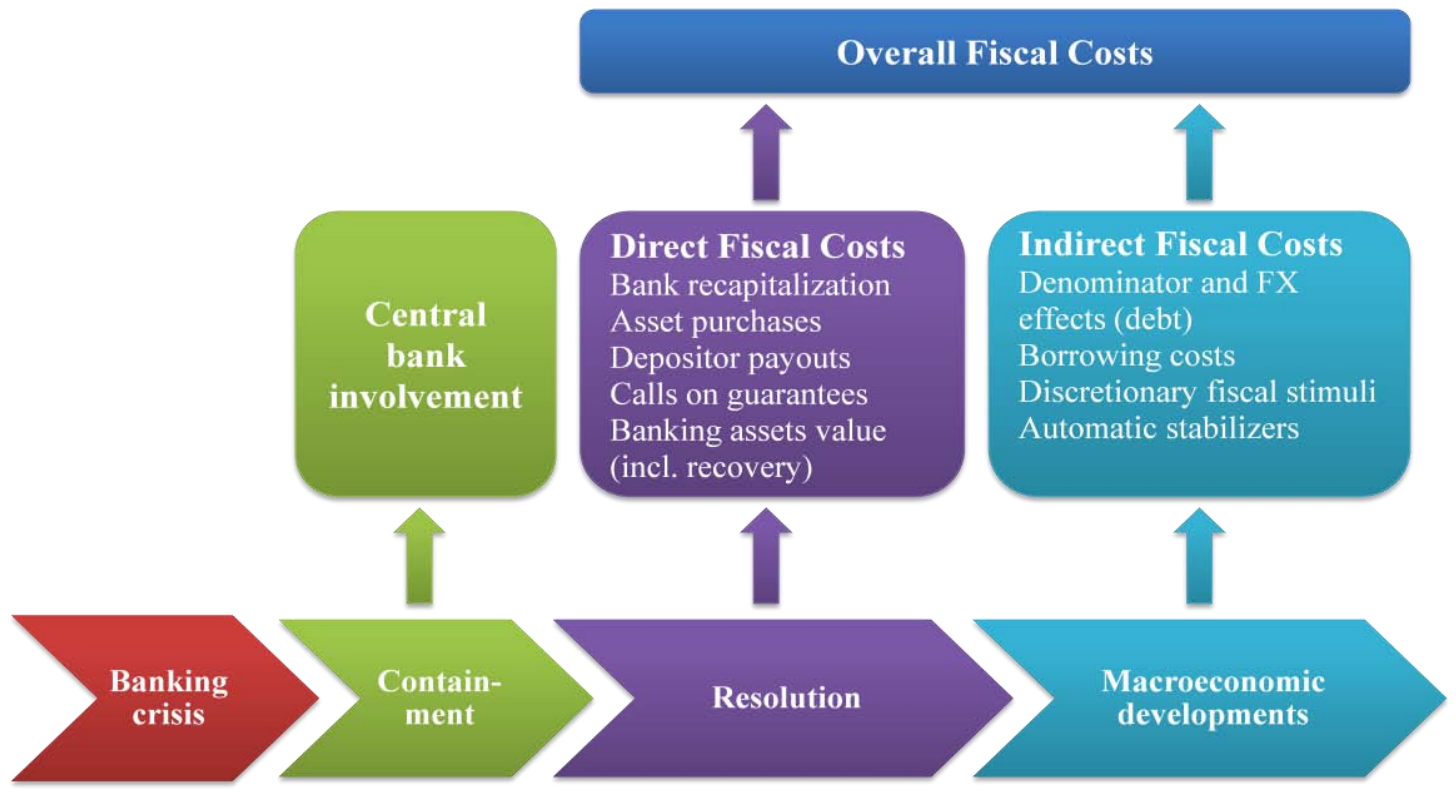

- Indirect fiscal costs. They are incurred through the impact of banking crises on the real economy, in particular on interest rates, GDP growth, and asset prices. Banking crises generally raise risk premia and disrupt the supply of credit to bank-dependent borrowers, who in turn reduce consumption and investment, with negative effects on aggregate demand, growth, and value of assets. These effects compound to reduce governments' revenue and create pressures on public spending - particularly when automatic stabilizers are large or when the need for a fiscal stimulus emerges - negatively affecting primary

\footnotetext{
${ }^{3}$ See, for example, EC (2009), Hoggarth and others (2002), and Reinhart and Rogoff (2008).
} 
balances and debt dynamics. In addition, interest expenditure can increase because of rising risk premia, liquidity shortage, and possible exchange rate reactions. ${ }^{4}$

- Overall fiscal costs. The direct and indirect effects of banking crises on public finances ultimately manifest in changes in gross public debt ratios, a more comprehensive measure of fiscal costs. ${ }^{5}$ However, increases in public debt may overstate the true cost of banking crises, as they also capture effects of other events that may occur around a banking crisis, including sovereign and currency crises. ${ }^{6}$

\section{B. Explaining Systemic Banking Crises and Fiscal Costs}

The theoretical and empirical literature has identified factors associated with the probability and size of crises. These factors can help explain the magnitude of the direct fiscal costs that crises carry: direct fiscal costs can be seen as the residual cost that falls on governments after discounting for automatic provisions, such as capital buffers, and private sector involvement (Honohan and Klingebiel, 2003). Therefore, factors leading up to a banking crisis are likely to explain the magnitude of direct fiscal costs.

\section{Factors associated with banking crises}

The literature on banking crises suggests that multiple precrisis economic and institutional factors may help explain the occurrence and the magnitude of crises:

- $\quad$ Precrisis macroeconomic conditions. Banking crises are typically preceded by credit booms, inflated asset prices and growth, and improved fiscal performance. The larger the initial imbalances, the higher the probability of a banking crisis (IADB, 2005). However, better external sector performance, reflected for example in better current account balances, provides more resilience to shocks hitting the financial sector (IMF, 1998).

- $\quad$ Precrisis features and vulnerabilities of the banking sector. Based on a simple model of banking crises under moral hazard, Honohan and Klingebiel (2003) suggested that the presence of financially strong banks would lower the probability of intervention. Other studies suggested that the size of the banking system and bank leverage amplify

\footnotetext{
${ }^{4}$ For instance, Escolano and others (2011) provide evidence about higher interest rate-growth differentials following banking crises, especially severe crises.

${ }^{5}$ Alternatively, net debt could be used as a measure of overall fiscal costs. Net debt would reflect initial costs and recoveries of these costs. Nevertheless, gross debt better captures the degree of immediate financial stress and data are usually more widely available than for net debt. In addition, net debt does not treat equally the different possible financing instruments of the public support.

${ }^{6}$ The literature examining the sequencing of various types of crises suggests that banking crises usually precede currency and sovereign debt crises (Gourinchas and Obstfeld, 2012; Kaminsky and Reinhart, 1999). The factors other than the banking crisis that may affect public debt include, for example, inflation, fiscal adjustment, and sovereign debt restructuring, explaining why in some cases public debt decreases after a banking crisis.
} 
banking sector stress and the probability of stress (Boissay and others, 2013; IMF, 2011; Kalemli-Ozcan and others, 2012). Similarly, firms' and households' excessive leveraging aggravates imbalances in the financial sector (Allen and Gale, 2003), international interconnectedness increases systemic risk (Cihak and others, 2011), and both these two factors increase the probability of banking crises.

- Institutional setting. The level of institutional development, including that of the institutions specific to the financial sector, affects the probability of having a banking crisis (Demirguc-Kunt and Detragiache, 1998), and the size of any public intervention if a crisis materializes (Claessens and others, 2005). Strong regulatory and supervisory frameworks, including the resolution framework, are expected to reduce the likelihood and size of a banking crisis by limiting the banking system's fragility (Claessens and others, 2005). Deposit insurance schemes - an important element of the banking sector safety net-could, in particular, have opposing forces at work that may affect the probability of a crisis. On the one hand, explicit insurance schemes by design should reduce the incidents of bank runs. On the other hand, these schemes could increase the probability of a crisis through higher moral hazard risks. Hence, the theory is inconclusive about the sign of correlation between deposit insurance and banking crises (Demirguc-Kunt and Detragiache, 1998). ${ }^{7}$ In addition, weaker institutions may affect the magnitude of a crisis, as they lead to less efficient crisis management policies and higher fiscal costs once crises occur (Claessens and others, 2005).

\section{Fiscal costs of banking crises}

Demirguc-Kunt and Detragiache (1998) first tested whether the underlying determinants of banking crises can explain observed differences in the severity of banking crises for the sovereign. They showed that variables correlated with the probability of a banking crisis are correlated with direct fiscal costs of banking crises. More specifically, they found evidence that, in addition to initial macroeconomic conditions, broad institutional setting and nonfinancial sector leverage have some bearing on direct fiscal costs. Hoggarth and others (2002) confirmed these findings, although using a more limited set of explanatory variables. Frydl (1999), by contrast, found no evidence of a correlation between the length of a crisis and the resolution costs.

Subsequent research focused on the role of policy responses and the institutional setting in explaining fiscal costs of banking crises. Honohan and Klingebiel (2003) showed that accommodating policies - such as blanket deposit guarantees, open-ended liquidity support, repeated recapitalizations, debtor bail-outs, and regulatory forbearance - tend to add to fiscal costs. Their finding does not account for the role of the institutional setting. Claessens and others (2005) showed that the effectiveness of policy responses tends to be associated with the general institutional environment, as reflected in the quality of the legislative and judicial

\footnotetext{
${ }^{7}$ Recovery rates are also a function of the quality of the institutions (European Commission, 2009, based on IMF, 2009).
} 
systems. However, their findings use specifications that control neither for initial macroeconomic conditions nor for financial sector characteristics that other contributions have identified as underlying causes of banking crises.

Although the determinants of direct fiscal costs have received attention, little research exists on factors likely to affect the overall fiscal costs of banking crises, and how specific policy interventions early in the crisis can affect these costs. ${ }^{8}$ However, there are various channels through which banking crises can have fiscal implications beyond immediate direct costs (Reinhart and Rogoff, 2008, 2013). Most important, a banking crisis is usually associated with a negative and protracted impact on growth (Boissay and others, 2013) and sometimes in the level of output, a fall in asset prices, and a possible breakdown in the payment system that typically lead to lower tax revenue, higher public expenditure, and increased public debt. For instance, Escolano and others (2011) provided some evidence for higher interest rategrowth differentials following banking crises, especially severe crises. In addition, policy measures with low initial costs might carry higher future costs not accounted as direct fiscal costs (e.g., government guarantees and regulatory forbearance; Claessens and others, 2005). Alternatively, costly initial interventions may smooth the macroeconomic impact of crises and lead over time to smaller overall costs (IMF, 2015).

The literature has important limitations, and this paper addresses three of them. First, we focus on both direct and overall fiscal costs, and we investigate trade-offs between the two. Second, we account for recent developments and complexities of the banking sector, such as international interconnectedness and external funding, and for the experience of the recent global financial crisis. Finally, we take into account the interactions among various risk factors, including macroeconomic and institutional variables, financial sector characteristics, and policy responses.

\section{Fiscal Costs of Banking CRises}

\section{A. Data}

Our analysis uses the Laeven and Valencia (2013) dataset of banking crises. The dataset includes direct fiscal costs defined as the sum of governments' recapitalization costs and asset purchases and, where relevant, they also include central banks' recapitalizations and loans to banks. This definition is somewhat different from the dichotomy presented in section II, as some direct costs that materialize later are not included here. ${ }^{9}$

Direct fiscal costs are broken down by policy instruments: bank recapitalizations, calls on guarantees, and asset purchases. Each instrument entails a specific impact on key fiscal

\footnotetext{
${ }^{8}$ The only exception to our knowledge is the European Commission (2009), which develops an estimation of the change in the public debt ratio attributable to the banking crises.

${ }^{9}$ Direct fiscal costs are defined on a gross basis, as they offer a better gauge of immediate financial pressure. An alternative would have been to use net fiscal costs. However, data coverage for net fiscal cost is limited and excludes the last wave of the banking crises.
} 
indicators. For example, fiscal balances are expected to worsen if direct costs give rise to public spending. However, if the government intervention is a pure "below-the-line" financial transaction, there is no effect on the fiscal balance, but gross public debt might increase, depending on how it is financed. If the government intervention leads to an increase in contingent liabilities, there is no immediate effect on fiscal accounts (Box 1).

In addition to fiscal data, we compiled macroeconomic, financial, and institutional variables from various databases. ${ }^{10}$ In particular, financial variables are derived from World Bank (2012). For public debt, Abbas and others (2011) supplied most observations, which we combined with general government gross debt-to-GDP series from Mauro and others (2013). We also used macro-fiscal data from the IMF's April 2014 World Economic Outlook and the banking supervision index built by Abiad and others (2008). Finally, Laeven and Valencia's (2013) database documents the existence and coverage of deposit insurance before the crisis, as well as the peak ratio of non-performing loans (NPLs).

As a result, we obtain a cross-sectional set of 65 banking crisis episodes from 1980 to 2011 that involves 56 high- and middle-income economies (Table A11). ${ }^{11}$

\section{B. Three Decades of Systemic Banking Crises: Stylized Facts}

The fiscal costs of banking crises, whether direct or overall, have been sizable. The sample median direct fiscal cost was about 6 percent of GDP; the median increase in public debt was more than 14 percent of GDP.

The variation in both direct fiscal costs and public debt dynamics across countries has been significant as well. Emerging economies have, on average, incurred direct fiscal costs twice as high as advanced economies; their increase in public debt-to-GDP ratios has been however only half, presumably reflecting smaller automatic stabilizers and less space to introduce countercyclical fiscal policies. Direct fiscal costs have been particularly high in Argentina, Chile, Iceland, Indonesia, Ireland, Jamaica, and Thailand; these countries faced sizable direct fiscal costs, above 40 percent of GDP. However, the increase in public debt around the banking crises exceeded 80 percent of GDP in Argentina and Chile (Figure 2), while it declined considerably in a few other countries.

\footnotetext{
${ }^{10}$ Table A10 provides a comprehensive summary of the variables and their sources.

${ }^{11}$ High- and middle-income countries are defined by gross national income per capita, according to the World Bank classification as of September 2014.
} 


\section{Box 1. Recording Direct Fiscal Costs of Banking Crises under the Government Financial Statistics Manual (GFSM 2001)}

The recording of the government's intervention in a financial institution in fiscal accounts depends on whether the government acquires an effective claim and on the mode of financing. Three main types of government interventions can be distinguished, each having different impact on key fiscal indicators, such as net lending/borrowing, overall balance, gross and net public debt:

(1) Requited recapitalization occurs when the government takes an equity stake, extends a loan or purchases a bad asset at the market value.

(2) Unrequited recapitalization occurs when the government injects capital in a bank but does not effectively receive any claim.

(3) The purchase of a bad asset at a premium occurs when the government acquires an asset in a bank at a cost higher than market value.

Table. Impact of government intervention in a financial institutions on key fiscal accounts 1 /

\begin{tabular}{|c|c|c|c|c|}
\hline & \multicolumn{4}{|c|}{ Nature of government intervention } \\
\hline & & Requited capitalization 2/ & Unrequited capitalization & Bad asset purchase at a premium \\
\hline 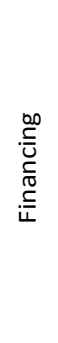 & Cash & $\begin{array}{l}\text { Net lending/Borrowing } X \\
\text { Overall Balance } \downarrow \\
\text { Gross Public Debt } \times \\
\text { Net Public Debt } X \\
\text { Net lending/Borrowing } X \\
\text { Overall Balance } \downarrow \\
\text { Gross Public Debt } \uparrow \\
\text { Net Public Debt } X\end{array}$ & $\begin{array}{l}\text { Net lending/Borrowing } \downarrow \\
\text { Overall Balance } \downarrow \\
\text { Gross Public Debt } \times \\
\text { Net Public Debt } \uparrow \\
\text { Net lending/Borrowing } \downarrow \\
\text { Overall Balance } \downarrow \\
\text { Gross Public Debt } \uparrow \\
\text { Net Public Debt } \uparrow\end{array}$ & $\begin{array}{l}\text { Net lending/Borrowing } \downarrow 3 \text { / } \\
\text { Overall Balance } \downarrow \text { 4/ } \\
\text { Gross Public Debt } \times \\
\text { Net Public Debt } \uparrow 3 / \\
\text { Net lending/Borrowing } \downarrow 3 \text { / } \\
\text { Overall Balance } \downarrow 4 \text { / } \\
\text { Gross Public Debt } \uparrow \text { 4/ } \\
\text { Net Public Debt } \uparrow 3 /\end{array}$ \\
\hline
\end{tabular}

Source: The state of public finances: outlook and medium-term policies after the 2008 crisis, 2009, IMF, companion paper.

Note: $X$ - no impact, $\downarrow$ decline in value, $\uparrow$ increase in value.

1/ Does not include the secondary impact of these operations (e.g. the impact of revenue through dividends received from an acquired asset. 2 / Includes taking an equity stake in a financial institution, extending a loan or purchasing a bad asset at the market value.

$3 /$ Changes by the amount of the difference between the market value and the purchase price.

4 / Changes by the amount of the purchase price.

Although challenging, proper valuation of acquired assets is a critical element of reporting a government's net worth position at any given point in time. Valuation at the time when the asset is acquired would determine whether the government is incurring any immediate loss from its intervention. Any subsequent change in the market value should be recorded as other economic flow, irrespective of whether the resulting gain/loss is realized. Such gains/losses have no impact on the net lending/borrowing balance, but they are reported in the statement of other economic flows and impact the government's net financial worth. However, a proper assessment of the government's net worth may be challenging, particularly during crises. The possibility of fire sales, uncertainty about recovery rates, and regulatory forbearance that tends to conceal the true value of banks' net worth pose significant challenges to assess properly the net worth position of governments around crisis events. 
Figure 2. Fiscal Costs During Selected Banking Crises

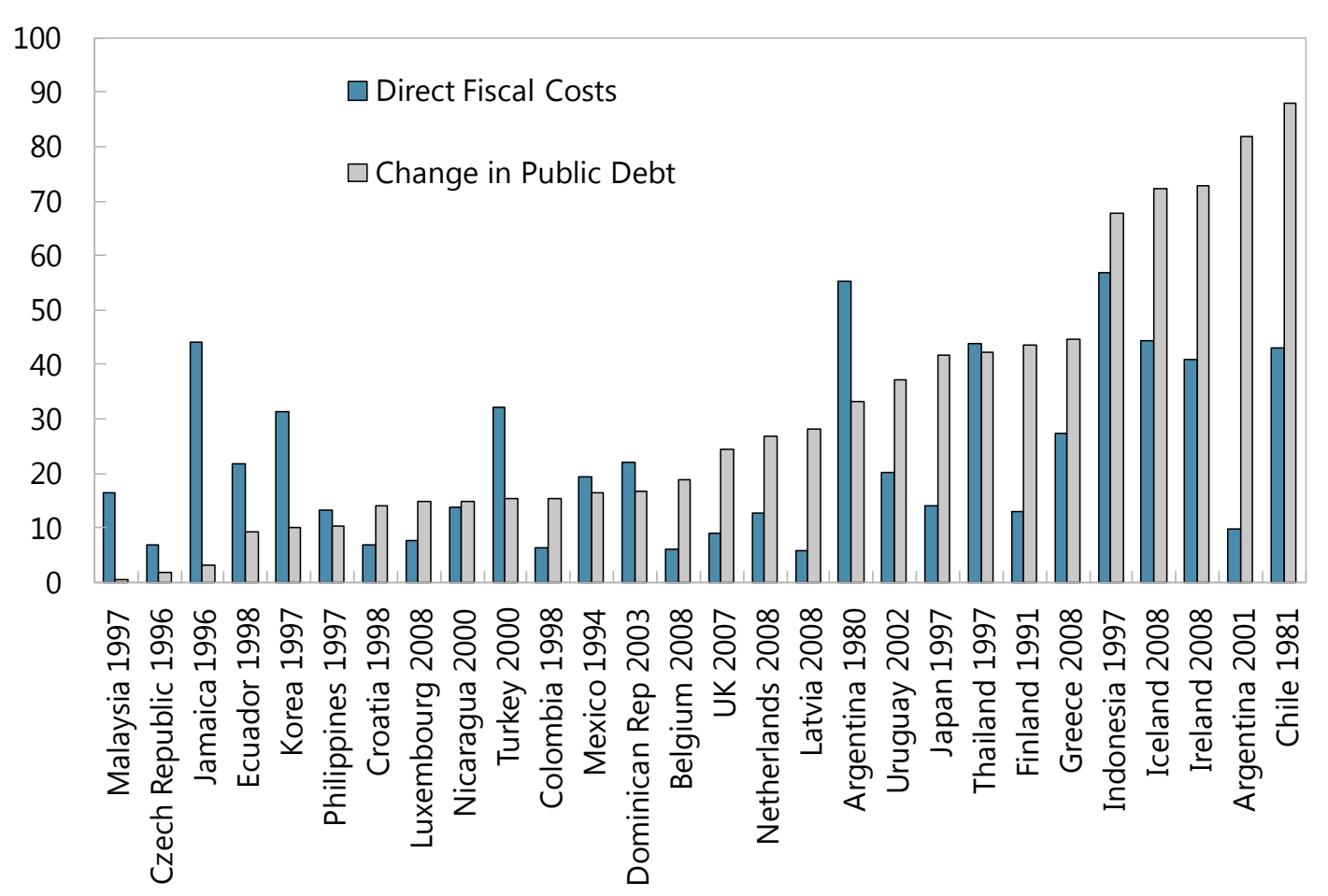

Note: This chart excludes cases with direct fiscal costs below five percent of GDP and seven cases with negative or close to zero change in public debt.

The magnitude of fiscal costs has also varied significantly across waves of banking crisis episodes (Figure 3). The costliest of all, both in terms of direct and overall fiscal costs, was the wave of five banking crises that occurred during 2000-03. During the most recent 200711 wave, which includes 25 systemic and borderline systemic banking crises predominantly affected advanced economies and direct fiscal costs of around 5 percent of GDP were low compared to previous crises. However, the increase in public debt of around 20 percent of GDP was particularly large. The limited role of direct fiscal costs in explaining the increase in public debt in recent crises possibly reflects the larger capacity of advanced economies to pursue countercyclical fiscal and monetary policies, larger automatic stabilizers, or larger banking systems.

Although initial direct fiscal costs summarize immediate fiscal pressures, they could overstate the fiscal costs of a crisis, because governments may recover some of their initial costs. Yet, the median recovery rate for the sample of 38 countries is only about 7 percent of gross fiscal costs. ${ }^{12}$ The maximum recovery rate of 94 percent was recorded in Sweden; no recoveries were achieved in about one third of the cases (Figure 4). Overall, the correlation in our sample between gross and net direct fiscal costs - i.e., before and after cost recovery - is quite high.

\footnotetext{
${ }^{12}$ Recovery rates are defined as recovery proceeds during the period $\mathrm{T}$ to $\mathrm{T}+5$, where $\mathrm{T}$ is the first year of the crisis, divided by the gross direct fiscal cost.
} 
Figure 3. Fiscal Costs Across Different Waves of Banking Crises
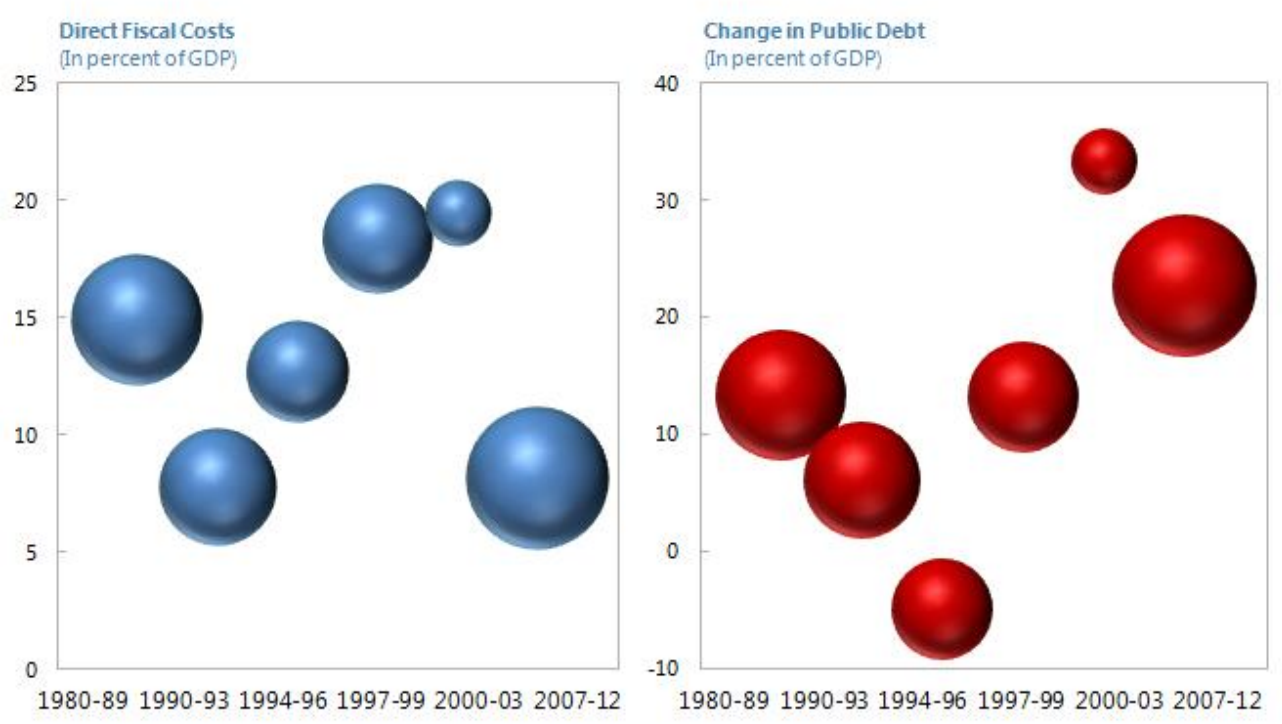

Source: Laeven and Valencia (2013).

Note: Bubbles represent the number of banking crisis episodes.

Figure 4. Recovery Rates Across Selected Banking Crises

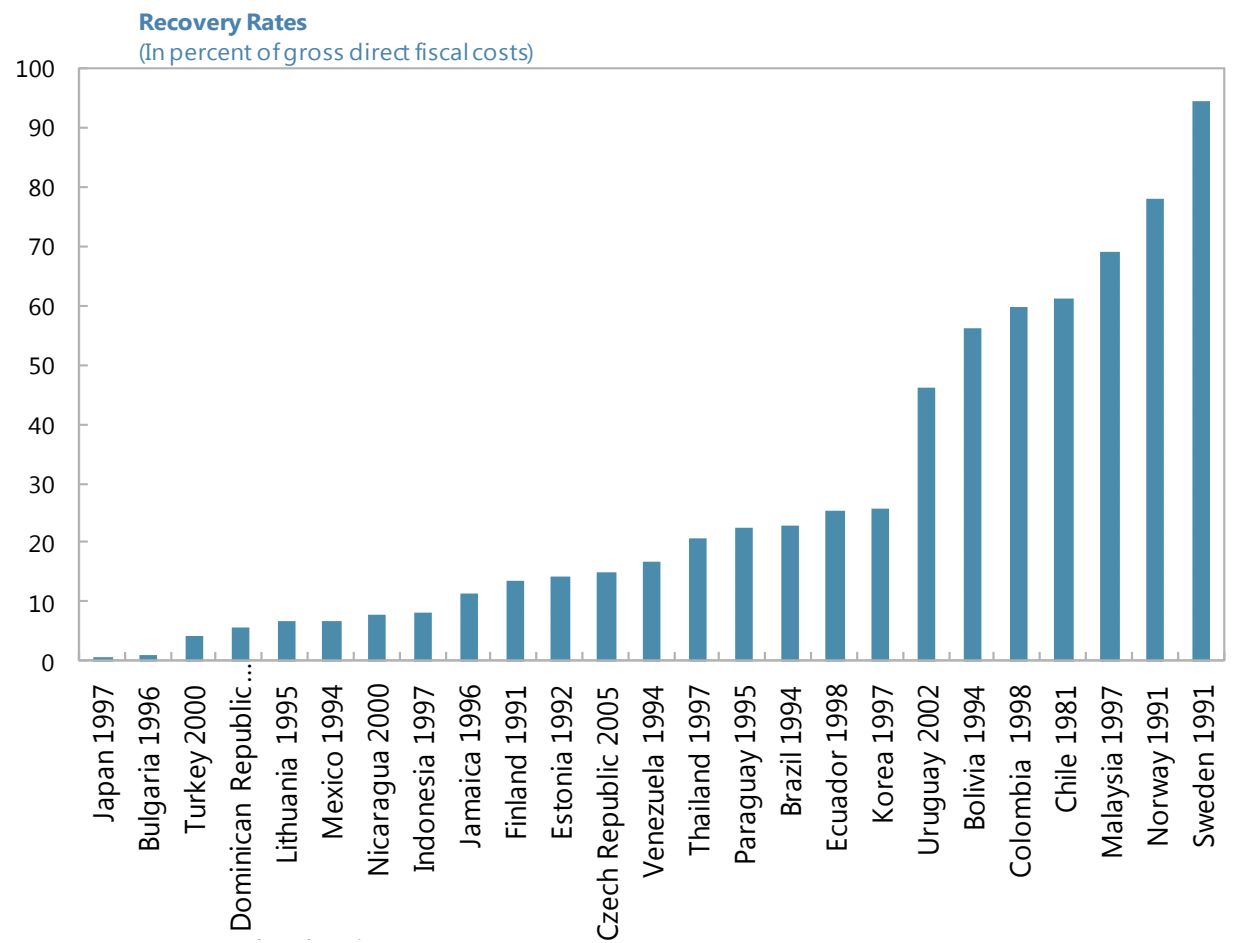

Source: Laeven and Valencia (2013). 
Increases in gross public debt-to-GDP ratios in the course of banking crises appear closely correlated with direct fiscal costs (Figure 5). This aggregate relation could nevertheless hide possible trade-offs between initial direct costs and overall costs. Initial direct costs could reflect efforts to contain output losses, which, in turn, could lead to lower increases in debt than otherwise. Several channels could help explain why having a high initial direct fiscal cost might not always lead to a high total cost. For example, high initial fiscal outlays could help quickly restore normal functioning of the financial sector. A healthier post-crisis financial sector means improved recovery rates, fewer guarantees called, lesser effect on interest rates and, most importantly, better mitigation of the negative effect on the output. Although the possibility of a trade-off between initial direct costs and overall fiscal costs does not emerge in aggregate data, the analysis in the following sections shows that such a trade-off is a distinct possibility.

Figure 5. Public Debt Increase and Direct Fiscal Costs of Banking Crises, 1970-2011

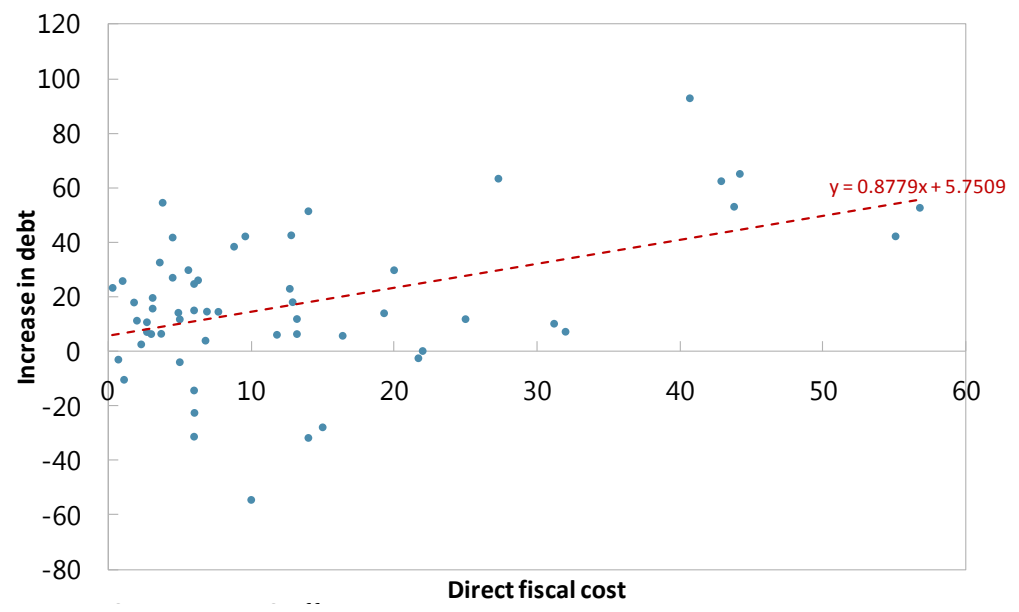

\section{Risk FACTORS OF DiRect Fiscal COSTS}

This section identifies risk factors associated with direct fiscal costs of systemic banking crises.

\section{A. Methodology}

We use both descriptive statistics and multivariate regression analysis to provide a stronger empirical base, given the relatively limited number of observations in our sample.

Several caveats apply to our analysis, some of which are addressed through robustness checks. First, since no reduced or structural model of fiscal costs exists, conditional correlations presented should be interpreted with caution, as they may not necessarily reflect 
causal relations. ${ }^{13}$ Second, governments' choice of crisis management strategies may account for much of the cross-country variation in observed costs; since policies cannot be known ex ante, there are possible reverse causality issues. Finally, the lack of historical indicators of banking system soundness and the limited number of crises limits the sample size.

\section{B. Descriptive Statistics}

Drawing on the literature on banking crises (Section II), we focus on the relation between direct fiscal costs of banking crises and three groups of variables: (i) precrisis financial sector characteristics; (ii) institutional settings; and (iii) policy responses following the onset of banking crises.

Simple cross-country descriptive statistics suggest that the size and leverage of the banking and nonbanking sectors are associated with direct fiscal costs. Specifically, countries with larger banking sectors, as measured by total banking sector assets-to-GDP ratios, are characterized by higher direct fiscal costs. Similarly, the higher the precrisis leverage of the banking sector (measured by the loan-to-deposit ratio) and the leverage of household and corporate sectors (measured by the private sector credit-to-GDP ratio), the higher the direct fiscal costs of banking crises (Figure 6). This initial evidence is consistent with findings from previous studies, for example, Hoggarth and others (2002) and IMF (2003), that used a much smaller sample of crises.

Figure 6. Average Direct Fiscal Costs, Cross-border Interconnectedness, and Size and Leverage of the Banking and Non-Banking Sectors

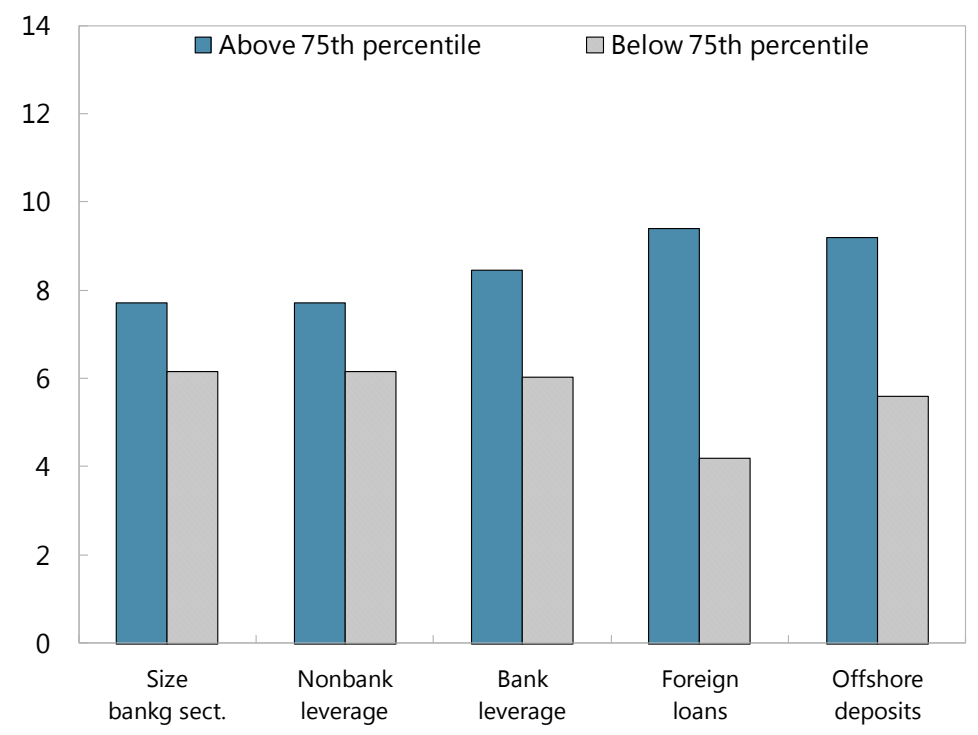

\footnotetext{
${ }^{13}$ Only Frydl and Quintyn (2000) provide an optimization framework based on a cost-benefit analysis of intervention measures for governments.
} 
As banking sectors have become increasingly complex and internationally interconnected, a natural question is whether such interconnectedness might pose additional fiscal risks. Simple statistics suggest that the extent of cross-border interconnectedness of national banking systems is indeed associated with high direct fiscal costs when crises occur. In particular, direct fiscal costs of banking crises are higher, as financing from non-resident bank loans as a share of GDP rises. Costs of banking crises are also higher as the the ratio of offshore deposits to domestic deposits increases (Figure 6). ${ }^{14}$

Countries' institutional development is often seen reducing banking sector vulnerabilites and should therefore help minimizing fiscal risks. In our sample, the degree of institutional development is indeed associated with direct fiscal costs of crises (Figure 7); in particular, countries with a higher overall level of institutional development and administrative capacity (proxied by the GDP per capita) tend to have lower direct fiscal costs in crises.

\section{Figure 7. Average Direct Fiscal Costs and Institutions}

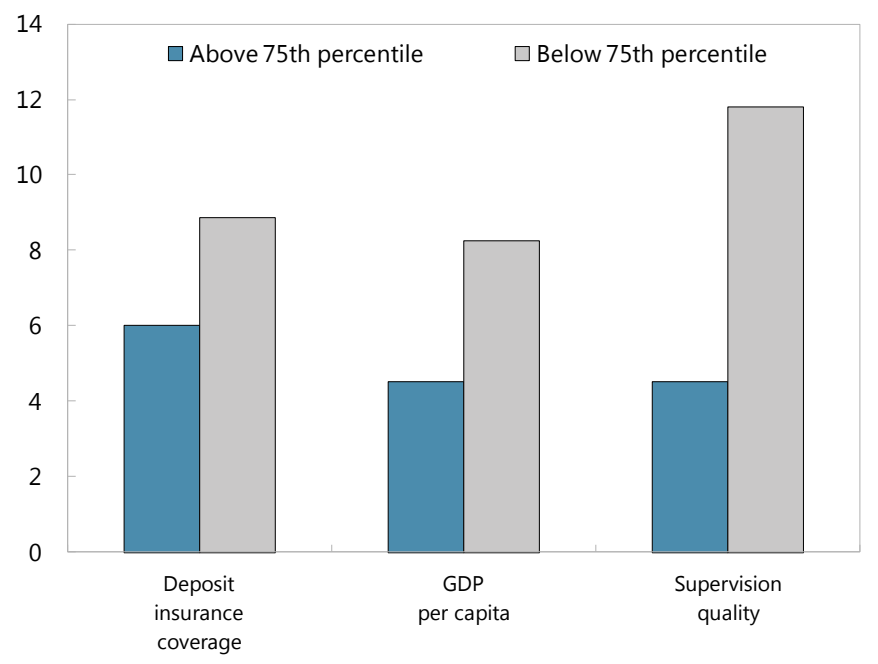

A more interesting and related question is whether a link exists between the regulatory and supervisory framework of the banking sector and fiscal costs from crises. In our sample, better quality of banking supervision, as measured by the banking supervision index (Abiad and others, 2008), is negatively correlated with fiscal costs. ${ }^{15}$ This correlation suggests that, even when a crisis occurs, well-functioning monitoring and regulatory frameworks still help contain direct fiscal costs in the event of a crisis, possibly by contributing to limit their magnitude. Data also show that direct fiscal costs are lower in countries that provide more generous safety nets. In particular, in our sample, broader deposit insurance coverage, as

\footnotetext{
${ }^{14}$ The measure of financing from loans from nonresident banks includes nonbanking sector in the domestic economy.

${ }^{15}$ The banking supervision index reflects the degree of adoption of risk-based capital adequacy principles, independence and legal power of the supervisory agency, institutional coverage of supervision, and effectiveness of examinations of banks.
} 
proxied by the ratio of insured deposits over per capita GDP, is associated with lower direct fiscal costs. This finding suggests that the presence of a meaningful deposit insurance coverage might reduce the risk of deposit runs and help contain the cost of crises. ${ }^{16}$ However, this correlation and the possible impact of wider deposit schemes on fiscal costs of crises have to be interpreted with caution. Countries with broader deposit insurances are also found to be more likely to experience crises (Demirguc-Kunt and Huizinga, 2004); hence, having a wider insurance scheme may not necessarily lead to lower direct fiscal costs once crisis probability is considered. ${ }^{17}$

How governments cope with a banking crises clearly affects the fiscal costs they are likely to face abd it is important to examine how specific policy decisions reflect in fiscal costs. Issues of reverse causality loom large, and we discuss possible endogenity issues in subsection D. We focus on two specific containment policies often adopted before any resolution measure: bank guarantees and forbearance in enforcing prudential and solvency regulations (Laeven and Valencia, 2013). Countries that provide guarantees on banks' liabilities following the start of the crisis or allow for regulatory forbearance have, on average, incurred higher direct fiscal costs (Figure 8). This correlation suggests that while guarantees may avoid upfront disbursements, they do not necessarily help contain direct fiscal costs over the crisis period. This finding may be due to reverse causality, as more severe crises may force governments to extend broader guarantees; in the subsequent analysis, we control for the size of shocks.

The correlation could also be due to the fact that guarantees are often not credible or sufficient to contain the crisis because of lack of fiscal space or international reserves in dollarized systems, thereby precipitating calls on guarantees. Moreover, it might be the case that issuing guarantees may encourage banks to assume higher risks, fueling banking stress and increasing the probability of guarantees being called. We do not delve into the possible causes of this result, but it is interesting to note that it contrasts with the effect of the coverage under deposit insurance schemes. The combination of two findings suggests that issuing new guarantees in the wake of a crisis is costlier for governments than having preexisting deposit insurance schemes. Finally, allowing for forbearance of rules and giving incentives for banks to "gamble for resurrection" eventually seems to cause larger costs for governments.

\footnotetext{
${ }^{16}$ An alternative reading is that, as insurance schemes are not funded by governments but by the banking sector itself, they limit governments' commitment to depositors. Higher ex ante coverage would imply that less public funds are needed in the event of a crisis.

${ }^{17}$ This result holds when controlling for institutional development (per capita GDP) and quality of banking supervision. Several studies suggest that the existence of deposit insurance schemes may increase direct fiscal costs of crises (e.g., Demirgüç-Kunt and Detragiache, 1998). However, these studies rely on limited samples, use outdated information, and only account for the existence, and not the coverage, of deposit insurance schemes.
} 
Figure 8. Average Direct Fiscal Costs and Crisis Policy Response: Containment and Resolution Phase

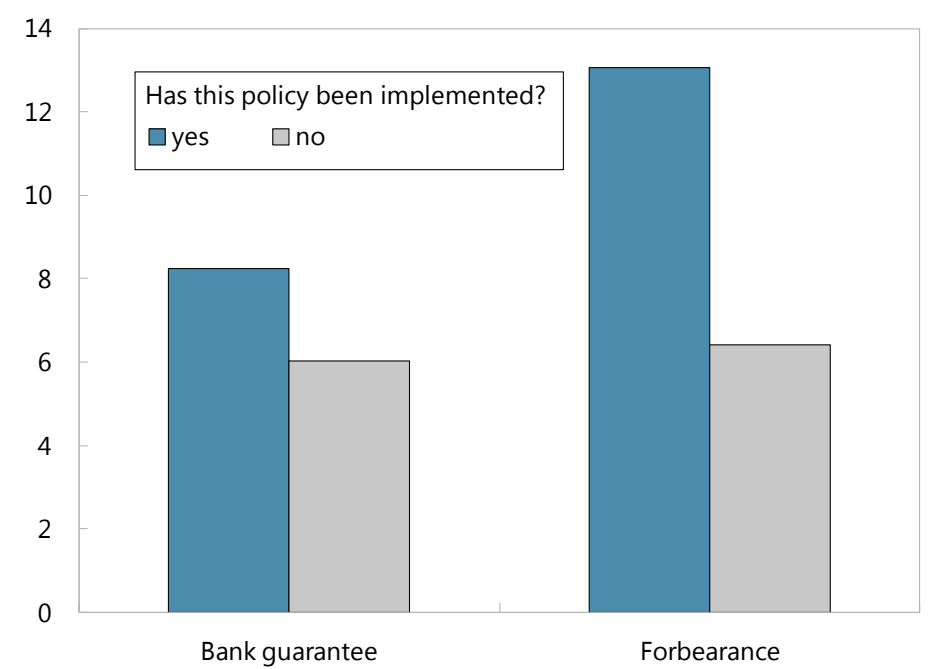

The experience with recent banking crises seems in line with the outcome of the sample of crisis episodes, as risk factors identified from past events have played a role in recent crises (Table 1). The main exception lies in the role of some institutional variables, such as the quality of banking supervision, which play little role in explaining cross-country differences in direct fiscal costs of the recent wave of crises. This can be explained by the fact that the majority of recent crises has occurred in advanced economies with similar levels of institutional development.

\section{Econometric Analysis}

We conduct a multivariate regression analysis to consider simultaneously the various variables that appear correlated to fiscal costs. Specifically, following the existing literature, we estimate the following equation:

$$
D F C_{i}=\alpha_{0}+\sum_{k=1}^{3} \alpha_{1, k} M V_{k, i}+\sum_{k=1}^{5} \alpha_{3, k} F V_{k, i}+\sum_{k=1}^{2} \alpha_{2, k} I S_{k, i}+\sum_{k=1}^{2} \alpha_{4, k} P R_{k, i}+\varepsilon_{i}
$$

where direct fiscal costs $\left(D F C_{i}\right)$ of crisis episode $i$ are a function of a set of precrisis macro variables $\left(M V_{k}\right)$, such as per capita income, public debt to GDP ratio, and current account balance, selected precrisis financial characteristics of the banking sector $\left(F V_{k}\right)$, institutional features $\left(I S_{k}\right)$, and governments' policy responses $\left(P R_{k}\right)$. 


\section{Table 1. Direct Fiscal Costs across Selected Vulnerability Indicators for Recent Banking Crises (2007-11) ${ }^{18}$}

\begin{tabular}{|c|c|c|c|}
\hline & \multicolumn{3}{|c|}{ Banking sector assets-to-GDP } \\
\hline & $\begin{array}{r}\text { Above } 75 \text { th } \\
\text { percentile }\end{array}$ & $\begin{array}{r}\text { Below } 75 \text { th } \\
\text { percentile }\end{array}$ & All sample \\
\hline Mean & 11.1 & 7.2 & 8.3 \\
\hline Median & 7.7 & 4.0 & 4.2 \\
\hline Standard Deviation & 13.6 & 11.1 & 11.7 \\
\hline Average banking sector assets-to-GDP & 179.2 & 89.5 & 114.6 \\
\hline Median banking sector assets-to-GDP & 182.1 & 95.2 & 115.9 \\
\hline \multirow[t]{3}{*}{ Number of observations } & 7 & 18 & 25 \\
\hline & \multicolumn{3}{|c|}{ Offshore deposits-to-total deposits } \\
\hline & $\begin{array}{r}\text { Above } 75 \text { th } \\
\text { percentile }\end{array}$ & $\begin{array}{r}\text { Below 75th } \\
\text { percentile }\end{array}$ & All sample \\
\hline Mean & 16.6 & 5.1 & 8.3 \\
\hline Median & 8.8 & 3.8 & 4.2 \\
\hline Standard Deviation & 18.2 & 6.1 & 11.7 \\
\hline Average offshore deposits-to-total deposits & 40.9 & 7.6 & 17.0 \\
\hline Median offshore deposits-to-total deposits & 30.4 & 6.2 & 9.6 \\
\hline \multirow[t]{3}{*}{ Number of observations } & 7 & 18 & 25 \\
\hline & \multicolumn{3}{|c|}{ Deposit insurance coverage limit-to-per capita GDP } \\
\hline & $\begin{array}{r}\text { Above } 75 \text { th } \\
\text { percentile }\end{array}$ & $\begin{array}{r}\text { Below } 75 \text { th } \\
\text { percentile }\end{array}$ & All sample \\
\hline Mean & 3.8 & 8.4 & 7.0 \\
\hline Median & 3.4 & 3.8 & 3.8 \\
\hline Standard Deviation & 3.2 & 11.6 & 10.0 \\
\hline Average deposit insurance coverage limit-to-per capita GDP & 264.5 & 77.8 & 133.8 \\
\hline Median deposit insurance coverage limit-to-per capita GDP & 268.4 & 70.4 & 91.1 \\
\hline \multirow[t]{3}{*}{ Number of observations } & 6 & 14 & 20 \\
\hline & \multicolumn{3}{|c|}{ Private sector credit-to-GDP } \\
\hline & $\begin{array}{r}\text { Above } 75 \text { th } \\
\text { percentile }\end{array}$ & $\begin{array}{r}\text { Below 75th } \\
\text { percentile }\end{array}$ & All sample \\
\hline Mean & 17.6 & 5.4 & 8.5 \\
\hline Median & 8.3 & 4.4 & 4.4 \\
\hline Standard Deviation & 19.7 & 6.3 & 11.9 \\
\hline Average private sector credit-to-GDP & 193.3 & 85.8 & 112.7 \\
\hline Median private sector credit-to-GDP & 179.7 & 85.2 & 102.1 \\
\hline \multirow[t]{3}{*}{ Number of observations } & 6 & 18 & 24 \\
\hline & \multicolumn{3}{|c|}{ Loans from nonresident banks-to-GDP } \\
\hline & $\begin{array}{r}\text { Above } 75 \text { th } \\
\text { percentile }\end{array}$ & $\begin{array}{r}\text { Below 75th } \\
\text { percentile }\end{array}$ & All sample \\
\hline Mean & 17.3 & 4.8 & 8.3 \\
\hline Median & 8.8 & 3.7 & 4.2 \\
\hline Standard Deviation & 17.5 & 6.2 & 11.7 \\
\hline Average loans from nonresident banks-to-GDP & 346.5 & 37.9 & 124.3 \\
\hline Median loans from nonresident banks-to-GDP & 223.6 & 34.0 & 53.0 \\
\hline \multirow[t]{3}{*}{ Number of observations } & 7 & 18 & 25 \\
\hline & \multicolumn{3}{|c|}{ Bank guarantees } \\
\hline & Used & Not used & All sample \\
\hline Mean & 9.3 & 3.1 & 8.5 \\
\hline Median & 4.5 & 3.7 & 4.4 \\
\hline Standard Deviation & 12.6 & 1.8 & 11.9 \\
\hline Number of observations & 21 & 3 & 24 \\
\hline
\end{tabular}

Source: Authors' calculations.

${ }^{18}$ Recent banking crises include system and borderline systemic banking crisis episodes (Laeven and Valencia, 2013). 
As a first step, we examine the role of precrisis characteristics of the banking sector and institutions, controlling for macroeconomic conditions. Regression results are broadly consistent with evidence from the descriptive statistics. Specifically, we find that the precrisis size of the banking sector (bank assets-to-GDP ratio), and the leverage of the non-financial sector (proxied by the private credit-to-GDP ratio) are significant and positively correlated with direct fiscal costs (Table A1a). Levels of international interconnectedness and external funding dependence (proxied by the loans from non-resident banks to total loans, and the ratio of offshore bank deposits to domestic deposits) are positively correlated with direct fiscal costs even when we control for all characteristics of the banking sector. Econometric analysis also confirms that banking sector institutions, such as the quality of supervision and the coverage of deposit insurance, are important for fiscal costs in that they are negatively correlated with direct fiscal costs (Tables A1b). Although previous studies find that the general level of institutional development of a country has a drag on fiscal costs (Claessens and others 2005; Demirguc-Kunt and Detragiache 1998; Honohan and Klingebiel, 2003), our results suggest that the specific regulatory and supervisory framework have particular importance. These findings suggest that recent trends toward more leveraged and internationally integrated banking sectors pose additional risks to public finances, but countries' regulatory and supervisory frameworks can help mitigate these risks.

We also look at the role that containment policies, such as bank guarantees and forbearance, can play with respect to fiscal costs of crises. Even when controlling for other factors, our results confirm that the choice of policy instrument is linked to the size of direct fiscal costs (Table A2). Specifically, while bank guarantees trigger no initial costs, in line with Honohan and Klingebiel (2003), we find that guarantees are associated with higher direct fiscal costs over the crisis period. Unlike these authors, we find only weak relation between forbearance and fiscal costs within our broader sample. ${ }^{19,20}$ Interestingly, introducing policy responses in our basic regression does not alter the significance of precrisis banking sector vulnerabilities.

Finally, we test whether our results hold for the most recent wave of banking crises (Table A3). We do this by interacting a dummy variable for recent crises with each of the explanatory variables of interest used in previous regressions. Results indicates that the interacting terms are no significant, suggesting that risk indicators identified for past crises are also relevant for recent crises. An exception arises for the quality of banking supervision and the measure of international interconnectedness that play less of a role in these crises, most likely because they occurred in economies with similar levels of institutional and financial development.

\footnotetext{
${ }^{19}$ The variable can be thought of as weakly correlated given that it is only significant in two specifications at 11 percent, and in one specification at 15 percent, while keeping the expected sign consistent with descriptive statistics.

${ }^{20}$ In an attempt to account for private sector involvement, a variable representing the losses imposed on depositors was used, but it turned out to be statistically insignificant across specifications. This variable, however, is defined as a dummy variable, so it does not capture the size of the private sector involvement and does not actually capture other creditors and shareholders.
} 


\section{Robustness Checks}

We run a set of robustness checks to control for the magnitude of the crisis shock and possible endogeneity issues related to the role of crisis management policies. Specifically:

- $\quad$ Accounting for the size of the shock. While our results show that, on average, our variables of interest significantly correlate with fiscal costs, one can assume that the results depend on the size of the shock. To account for this effect, we introduce in the regression the peak level of non-performing loan (NPL) ratio during the crisis. Results remain broadly similar compared to the benchmark regressions, with size of the banking sector and forbearance becoming less significant though (Table A4).

- $\quad$ Accounting for endogeneity. To account for reverse causality issues, we instrument policy variables in our basic regression (1) with an institutional variable and timing dummy variables, as in Honohan and Klingebiel (2003). The instrument is a measure of creditor rights constructed by Djankov and others (2007) that is assumed to reflect a dimension of institutional framework and capture the extent to which equity and creditor rights may be enforced and the judiciary system works efficiently. We use the Generalized Method of Moments (GMM). The new regression confirms results obtained under the ordinary least square (Table A5); hence, reverse causality is likely not a problem for the interpretation of the results.

\section{Risk FACTORS OF OVERALl Fiscal COSTS}

In this section, we look at the overall fiscal costs of banking crises. We explore whether risk factors identified in section IV are as significant for overall fiscal costs as for direct costs of crises. In addition, we investigate whether a relation exists between immediate direct fiscal costs of crisis intervention and overall fiscal costs of crises. As discussed, we define overall fiscal costs as changes in the debt-to-GDP ratio between the year before the onset of the crisis and four years after. We also use alternative time horizons. This is an imperfect approach, but it is a more comprehensive measure of fiscal costs than direct costs and provides additional insights on the costs of banking crises.

\section{A. Methodology}

We use both descriptive statistics and multivariate regression analysis. For the regression analysis, we rely on the basic stock-flow debt equation. This equation links debt changes to the primary fiscal balance, the differential between growth and interest rates, and stock-flow adjustments, given the initial stock of debt. Drawing on the empirical literature on the effects of banking crises on both output and interest rates (section II), we assume that the interest rate-growth differential depends on initial macro-fiscal conditions, precrisis financial sector characteristics, institutional variables, and policy decisions.

Results for overall fiscal costs have to be interpreted with caution. First, we do not estimate a full reduced-form relation derived from a specific structural model of the economy; hence, correlations may not necessarily reflect causal links. A related complicating factor is the possibility of reverse causality, especially as far as policy response variables are used as 
exogenous variables. Second, our dataset is fairly modest, especially when considering specific banking sector indicators, a factor that hinges on the robustness of some results.

\section{B. Descriptive Statistics}

Drawing on previous results on direct fiscal costs, we explore the relationship between overall fiscal costs and identified risk factors.

Simple descriptive analysis suggests that most of the risk factors relevant for direct fiscal costs play a role for overall fiscal costs (Table 2). Specifically, the size and leverage of the banking and nonbanking sectors are positively associated with overall fiscal costs. Moreover, the extent of cross-border interconnectedness appears to be associated with costlier banking crises. Contrary to the case of direct fiscal costs, though, overall fiscal costs are higher in countries with broader deposit insurance coverage. This correlation suggests that long-run costs arising from moral hazard outweigh the short-term benefits of initially reducing the risks of bank runs.

The type of policy intervention adopted during crises appears to have an unexpected bearing on overall fiscal costs (Figure 9). When we look at containment policies, for example, countries that have provided guarantees on banks' liabilities after the onset of the crisis and have allowed for regulatory forbearance have, on average, incurred higher overall costs. This correlation is in line with results about direct fiscal costs and suggests that policies that initially have little or no cost can be costly for public debt over time.

Interestingly, some of the measures that may carry immediate high direct costs are not necessarily associated with larger increases in public debt. More precisely, costly asset purchases during crises are not necessarily associated with higher overall costs over time. Initial costly interventions may thus be a cost-effective way to address crises (IMF 2015).

Figure 9. Average Overall Fiscal Costs and Policy Responses

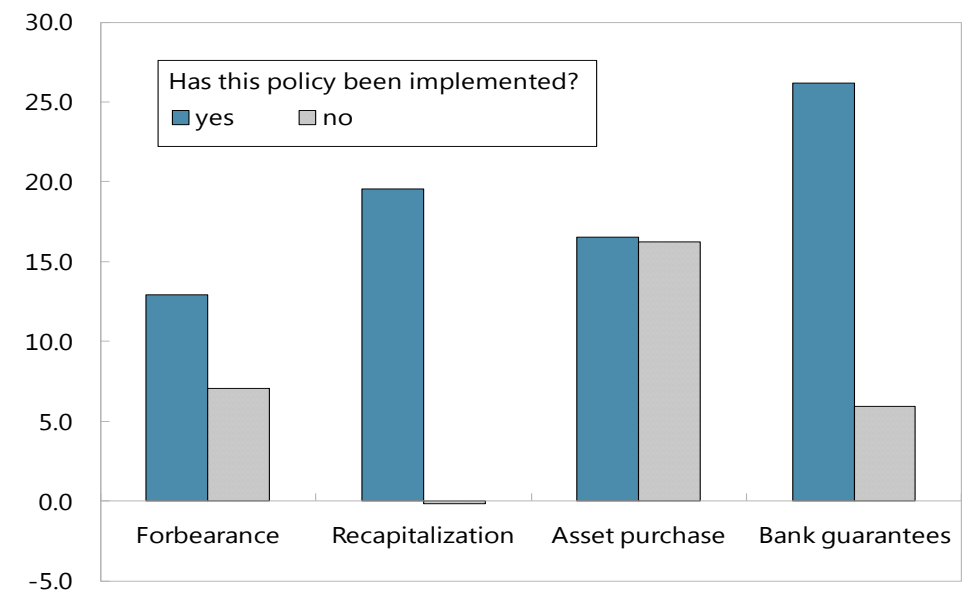


Table 2. Overall Fiscal Costs across Selected Vulnerability Indicators

\begin{tabular}{|c|c|c|c|c|c|c|}
\hline & \multicolumn{3}{|c|}{ Whole sample (1980-2011) } & \multicolumn{3}{|c|}{ Recent episodes (2007-2011) } \\
\hline & \multicolumn{6}{|c|}{ Banking sector assets-to-GDP } \\
\hline & $\begin{array}{l}\text { Above } 75 \text { th } \\
\text { percentile }\end{array}$ & $\begin{array}{l}\text { Below 75th } \\
\text { percentile }\end{array}$ & All sample & $\begin{array}{l}\text { Above 75th } \\
\text { percentile }\end{array}$ & $\begin{array}{l}\text { Below 75th } \\
\text { percentile }\end{array}$ & All sample \\
\hline Mean overall fiscal cost & 32.5 & 12.4 & 17.4 & 32.3 & 25.3 & 27.2 \\
\hline Median overall fiscal cost & 22.9 & 11.7 & 14.3 & 21.2 & 23.2 & 22.9 \\
\hline Standard Deviation & 28.4 & 24.2 & 26.5 & 36.2 & 20.6 & 24.8 \\
\hline Average banking sector assets-to-GDP & 163.8 & 46.6 & 75.9 & 182.5 & 97.6 & 119.7 \\
\hline Median banking sector assets-to-GDP & 159.6 & 39.2 & 52.9 & 183.3 & 107.1 & 122.1 \\
\hline \multirow[t]{3}{*}{ Number of observations } & 15 & 45 & 60 & 6 & 17 & 23 \\
\hline & \multicolumn{6}{|c|}{ Offshore deposits-to-total deposits } \\
\hline & $\begin{array}{l}\text { Above 75th } \\
\text { percentile }\end{array}$ & $\begin{array}{l}\text { Below 75th } \\
\text { percentile }\end{array}$ & All sample & $\begin{array}{l}\text { Above 75th } \\
\text { percentile }\end{array}$ & $\begin{array}{l}\text { Below 75th } \\
\text { percentile }\end{array}$ & All sample \\
\hline Mean overall fiscal cost & 29.3 & 17.0 & 20.3 & 37.2 & 23.6 & 27.2 \\
\hline Median overall fiscal cost & 26.0 & 14.3 & 15.0 & 30.6 & 19.6 & 22.9 \\
\hline Standard Deviation & 30.1 & 26.0 & 27.4 & 37.1 & 19.2 & 24.8 \\
\hline Average offshore deposits-to-total deposits & 36.7 & 7.4 & 15.3 & 45.2 & 8.1 & 17.8 \\
\hline Median offshore deposits-to-total deposits & 30.4 & 6.2 & 9.6 & 38.5 & 6.3 & 9.6 \\
\hline \multirow[t]{3}{*}{ Number of observations } & 11 & 30 & 41 & 6 & 17 & 23 \\
\hline & \multicolumn{6}{|c|}{ Deposit insurance coverage limit-to-per capita GDP } \\
\hline & $\begin{array}{l}\text { Above 75th } \\
\text { percentile }\end{array}$ & $\begin{array}{l}\text { Below 75th } \\
\text { percentile }\end{array}$ & All sample & $\begin{array}{l}\text { Above 75th } \\
\text { percentile }\end{array}$ & $\begin{array}{l}\text { Below 75th } \\
\text { percentile }\end{array}$ & All sample \\
\hline Mean overall fiscal cost & 15.5 & 14.9 & 15.1 & 25.7 & 25.6 & 25.6 \\
\hline Median overall fiscal cost & 17.5 & 14.3 & 14.3 & 26.4 & 17.9 & 22.9 \\
\hline Standard Deviation & 19.8 & 30.0 & 27.6 & 11.2 & 26.8 & 23.5 \\
\hline Average deposit insurance coverage limit-to-per capita GDP & 338.9 & 49.2 & 124.3 & 286.1 & 83.5 & 136.4 \\
\hline Median deposit insurance coverage limit-to-per capita GDP & 322.3 & 34.5 & 70.4 & 272.4 & 73.2 & 96.9 \\
\hline \multirow[t]{3}{*}{ Number of observations } & 14 & 40 & 54 & 6 & 17 & 23 \\
\hline & \multicolumn{6}{|c|}{ Private sector credit-to-GDP } \\
\hline & $\begin{array}{l}\text { Above } 75 \text { th } \\
\text { percentile }\end{array}$ & $\begin{array}{l}\text { Below 75th } \\
\text { percentile }\end{array}$ & All sample & $\begin{array}{l}\text { Above } 75 \text { th } \\
\text { percentile }\end{array}$ & $\begin{array}{l}\text { Below 75th } \\
\text { percentile }\end{array}$ & All sample \\
\hline Mean overall fiscal cost & 34.1 & 11.9 & 17.4 & 49.4 & 19.3 & 27.2 \\
\hline Median overall fiscal cost & 38.4 & 11.7 & 14.3 & 48.1 & 15.0 & 22.9 \\
\hline Standard Deviation & 28.2 & 23.8 & 26.5 & 27.6 & 19.0 & 24.8 \\
\hline Average private sector credit-to-GDP & 167.8 & 42.6 & 73.9 & 197.7 & 95.4 & 122.1 \\
\hline Median private sector credit-to-GDP & 166.0 & 35.1 & 47.3 & 187.7 & 95.1 & 111.6 \\
\hline \multirow[t]{3}{*}{ Number of observations } & 15 & 45 & 60 & 6 & 17 & 23 \\
\hline & \multicolumn{6}{|c|}{ Loans from nonresident banks-to-GDP } \\
\hline & $\begin{array}{l}\text { Above 75th } \\
\text { percentile }\end{array}$ & $\begin{array}{l}\text { Below 75th } \\
\text { percentile }\end{array}$ & All sample & $\begin{array}{l}\text { Above 75th } \\
\text { percentile }\end{array}$ & $\begin{array}{l}\text { Below 75th } \\
\text { percentile }\end{array}$ & All sample \\
\hline Mean overall fiscal cost & 33.5 & 13.6 & 18.7 & 37.2 & 24.0 & 27.3 \\
\hline Median overall fiscal cost & 29.8 & 11.0 & 15.0 & 30.6 & 21.4 & 23.1 \\
\hline Standard Deviation & 27.9 & 28.6 & 29.5 & 37.1 & 18.7 & 24.3 \\
\hline Average loans from nonresident banks-to-GDP & 246.7 & 21.6 & 79.2 & 383.8 & 44.5 & 129.3 \\
\hline Median loans from nonresident banks-to-GDP & 128.5 & 15.7 & 24.4 & 224.4 & 35.8 & 56.4 \\
\hline \multirow[t]{3}{*}{ Number of observations } & 11 & 32 & 43 & 6 & 18 & 24 \\
\hline & \multicolumn{6}{|c|}{ Bank credit to bank deposits } \\
\hline & $\begin{array}{l}\text { Above } 75 \text { th } \\
\text { percentile }\end{array}$ & $\begin{array}{l}\text { Below 75th } \\
\text { percentile }\end{array}$ & All sample & $\begin{array}{l}\text { Above 75th } \\
\text { percentile }\end{array}$ & $\begin{array}{l}\text { Below 75th } \\
\text { percentile }\end{array}$ & All sample \\
\hline Mean overall fiscal cost & 27.3 & 12.1 & 15.9 & 35.1 & 24.4 & 27.2 \\
\hline Median overall fiscal cost & 27.0 & 11.8 & 14.0 & 24.7 & 22.9 & 22.9 \\
\hline Standard Deviation & 35.8 & 24.6 & 28.3 & 36.8 & 19.8 & 24.8 \\
\hline Average bank credit to bank deposits & 258.4 & 103.1 & 141.9 & 335.7 & 116.7 & 173.8 \\
\hline Median bank credit to bank deposits & 182.8 & 112.9 & 119.1 & 238.1 & 123.9 & 135.3 \\
\hline \multirow[t]{3}{*}{ Number of observations } & 15 & 45 & 60 & 6 & 17 & 23 \\
\hline & \multicolumn{6}{|c|}{ Bank guarantees } \\
\hline & Used & Not used & All sample & Used & Not used & All sample \\
\hline Mean overall fiscal cost & 26.2 & 6.0 & 16.4 & 30.1 & 7.6 & 27.3 \\
\hline Median overall fiscal cost & 23.1 & 8.5 & 14.3 & 23.2 & 6.4 & 23.1 \\
\hline Standard Deviation & 27.7 & 24.6 & 28.0 & 24.0 & 18.8 & 24.3 \\
\hline Number of observations & 32 & 30 & 62 & 21 & 3 & 24 \\
\hline
\end{tabular}

Source: Authors' calculations.

Notes: The overall fiscal cost is defined as the change in public debt ratios over [T-1; T+4], where $\mathrm{T}$ is the starting year of the banking crisis. 
The experience with the most recent wave of banking crises does not appear to be particularly different from the outcomes for the whole sample (Table 2, right column). The only noticeable difference is the link between overall fiscal costs and the precrisis level of public debt (Figure 10). In past crises, overall fiscal costs were negatively correlated to the initial stock of debt, arguably because higher initial levels of public debt restrict the ability of governments to implement countercyclical fiscal policy during crises. However, overall fiscal costs during the recent episodes appear to be higher for countries entering the crisis with a higher debt-to-GDP ratio. This difference might be due to the fact that recent crises mainly involved advanced economies that tend to register larger debt increases on average, as they implement counter-cyclical policies and face less market constraints.

\section{Figure 10. Overall Fiscal Costs and Precrisis Level of Debt-to-GDP}

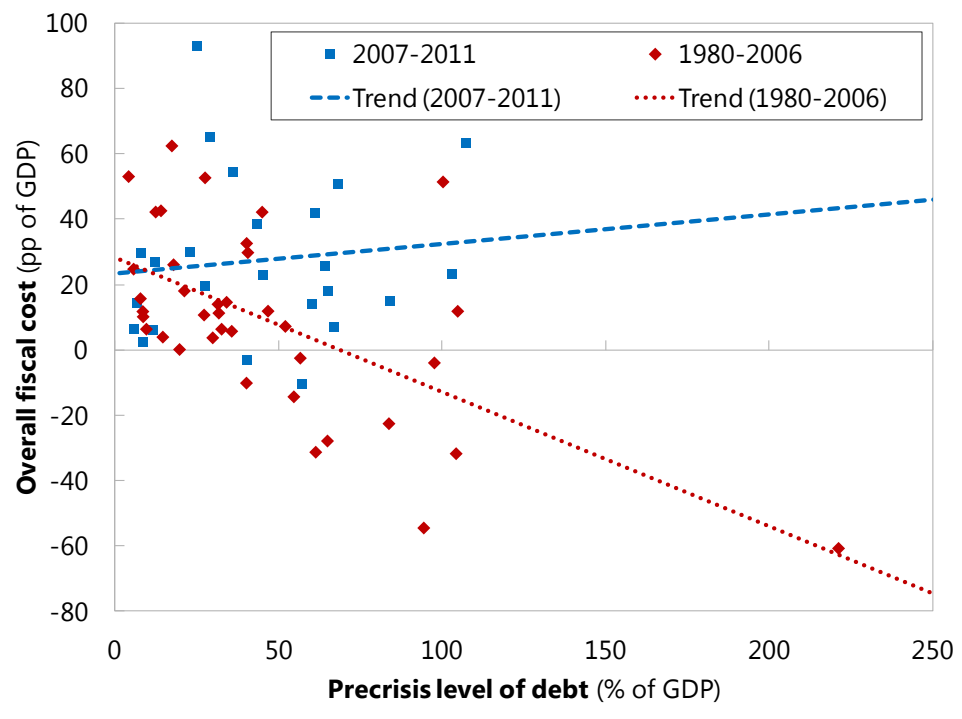

\section{Econometric Analysis}

Our econometric analysis is based on a modified stock-flow debt equation:

$$
O F C_{i}=\alpha_{0}+\alpha_{1} D_{0, i}+\alpha_{2} \Delta P B_{i}+\sum_{k} \alpha_{3, k} F V_{k, i}+\sum_{k} \alpha_{4, k} I S_{k, i}+\sum_{k} \alpha_{5, k} P R_{k, i}+\varepsilon_{i}
$$

In this equation, overall fiscal costs depend on: (i) the precrisis level of debt $D_{0}$, which plays a mechanical role through the interest-growth rate differential, but could also proxy, as discussed above, the available fiscal space for accommodative policies; (ii) the change in primary balance during the crisis $\triangle P B$; (iii) precrisis financial sector characteristics $\left(F V_{k}\right)$, summarized by financial and non-financial sector leverage, cross-border interconnectedness, and the size of the banking system; (iv) institutional variables $\left(I S_{k}\right)$, namely the quality of banking supervision and the degree of coverage of the deposit insurance; and (v) policy responses $\left(P R_{k}\right)$. For policy responses, in addition to the two variables used in the case of 
direct fiscal costs_- bank guarantees and forbearance — we include asset purchases and bank recapitalization.

Similar to direct fiscal costs, regressions confirm that overall fiscal costs of banking crises are higher when countries enter crises with larger and more leveraged banking sectors (Table A6). Unlike direct fiscal costs, though, overall costs tend to be higher in countries where banks have higher loan-to-deposit ratios; indicators of cross-country interconnectedness of banking systems have no relevance for the overall costs of crises. However, if we interpret the loan-to-deposit ratio as an indicator of the funding mix of banks, the first result suggests that the banking sector leverage and funding mix carry fiscal risks and countries with more leveraged banking sectors tend to face higher overall fiscal costs in crises. When controlling for the quality of banking supervision, indicators of banking sector funding mix appear less relevant for overall fiscal costs. This result suggests that when the banking supervisor keeps banks under control, their funding mix is not as important to overall fiscal costs; problems can still arise from the size and private sector debt overhang.

We also look at the role of policy interventions in explaining overall fiscal costs and whether initial costly interventions lead to high overall costs over time. We find that crisis management policies that have high initial costs are not necessarily costlier over time and vice versa for initial low-cost policies, such as guarantees. Specifically, bank guarantees that carry initial zero costs are unequivocally associated with higher overall costs (Table A7). At the same time, asset purchases and bank recapitalizations - policies that may have higher upfront costs - are not correlated with an increase in public debt. These findings confirm the presumption that there are trade-offs between costly short-term policy interventions and the overall increase in public debt.

\section{Robustness Checks}

We run robustness checks to test for different definitions of overall fiscal costs, the size of the crisis shock, and possible endogeneity issues:

- Changing the time dimension of the dependent variable. In our main set-up, overall fiscal costs are computed as the change in debt-to-GDP ratios over a period of five years-the change between the precrisis level and four years after the crisis. Alternatively, we have run our regressions using the increase in debt over four and six years, obtaining substantially the same results. Generally speaking, coefficients are smaller, the shorter the time span considered, which seems to confirm that some effects materialize only after several years.

- Accounting for the size of the shock (Table A8). Our results show that, on average, our variables of interest have significant correlation with fiscal costs, but results might depend on the size of the shock and private sector involvement. To account for these effects, we introduce the peak in the ratio of NPLs to total loans during the crisis as a measure of the size of the shock; we also include in our regression a dummy variable indicating whether losses were inflicted on depositors as a result of 
the crisis (Table A8). ${ }^{21}$ Results remain broadly similar to the benchmark regressions; losses imposed to depositors nor NPLs appear statistically significant.

- Accounting for endogeneity (Table A9). As in section IV, we instrument the policy variables in the extended model with time dummy variables and the creditor rights variable constructed by Djankov and others (2007) as a proxy of the institutional framework. With the GMM estimators, results are less significant than with ordinary least squares for precrisis variables, but more significant for policy response variables.

\section{Conclusions}

This paper sheds new light on the fiscal costs of systemic banking crises. Unlike previous research, which focused on direct fiscal costs of banking crises, this paper also examines overall fiscal costs.

We identify risk factors such as precrisis macroeconomic, financial, and institutional conditions that help explain the size of fiscal costs. We explore the impact of policy choices on both direct and overall fiscal costs, and we highlight a possible trade-off between policies that have initial costs but that may reduce later deterioration of fiscal accounts. We find that direct fiscal costs of banking crises are higher in countries where the banking sectors are larger, more leveraged, and more reliant on external funding. However, better institutionsparticularly better banking supervision — and broader deposit insurance coverage are associated with lower direct fiscal costs of crises. Hence, countries' regulatory and supervisory frameworks can help mitigate fiscal risks arising from modern banking systems. Most of these factors matter for overall fiscal costs, but policy responses seem to have a differential impact on fiscal costs of crises. For example, bank guarantees appear to increase both direct and overall fiscal costs, but the correlation is less clear-cut for other policy measures such as recapitalizations and asset purchases. These latter short-term measures carry initial direct costs but do not necessarily add to the overall fiscal costs of crises, as summarized by changes in the public debt-to-GDP ratio. This result suggests that some early policy interventions present a possible trade-off between costly short-term policies and overall increase in public debt.

These findings are important for policymakers. Risks and costs that spill over from the banking sector to the sovereign cannot be entirely eliminated, regardless of the lossabsorbing capacity of banking sectors. Our results suggest governments should identify and monitor specific risk indicators from the banking sector and develop expertise to evaluate the potential impact of banking vulnerabilities on fiscal and debt sustainability. Moreover, governments could benefit by acting early in crises.

\footnotetext{
${ }^{21}$ The variable for the private sector involvement was not statistically significant. However, this could be because it is defined as a binary variable and does not capture the severity of the losses imposed on the private sector.
} 
Looking forward, several areas merit further research, including developing a more refined measure of the overall fiscal cost and identifying the part of the change in public debt specifically due to banking crises. In addition, it would be useful to study the factors underlying recovery rates and crisis duration, which could help policymakers judge the costs and benefits of their interventions. Finally, it would be interesting to study whether banks' ownership structure, in particular the presence of foreign or sovereign shareholders, has any bearing on the fiscal costs of banking crises. 


\section{APPENDiX TABLES}

Table A1a. Basic Model: Conditional Correlations of Direct Fiscal Costs

\begin{tabular}{|c|c|c|c|c|c|}
\hline & (1) & (2) & (3) & (4) & (5) \\
\hline \multirow[t]{2}{*}{ Income per capita (t-1) } & -0.00300 & -0.00291 & 0.000124 & -0.000202 & -0.00138 \\
\hline & $(0.00179)$ & $(0.00181)$ & $(0.00157)$ & $(0.00205)$ & (0.00209) \\
\hline \multirow[t]{2}{*}{ Public debt/GDP (t-1) } & -0.00369 & -0.00495 & -0.00412 & -0.00713 & -0.00441 \\
\hline & $(0.00529)$ & $(0.00527)$ & (0.00367) & $(0.00776)$ & $(0.00374)$ \\
\hline \multirow[t]{2}{*}{ Current account/GDP (t-1) } & -0.0287 & -0.0325 & $-0.0475^{*}$ & $-0.0516 *$ & -0.0448 \\
\hline & $(0.0263)$ & $(0.0263)$ & $(0.0283)$ & (0.0295) & (0.0298) \\
\hline \multirow[t]{2}{*}{ Banking supervision index } & $-0.443 * * *$ & $-0.428 * * *$ & $-0.403 * * *$ & $-0.545^{* *}$ & $-0.615 * * *$ \\
\hline & $(0.125)$ & $(0.120)$ & $(0.132)$ & $(0.202)$ & (0.177) \\
\hline \multirow{2}{*}{$\begin{array}{l}\text { Non-financial sector leverage } \\
\text { (private credit/GDP, t-1) }\end{array}$} & $0.00871 * *$ & & & & \\
\hline & $(0.00376)$ & & & & \\
\hline \multirow{2}{*}{$\begin{array}{l}\text { Size of financial sector } \\
\text { (assets/GDP, t-1) }\end{array}$} & & $0.00771 * *$ & & & \\
\hline & & $(0.00320)$ & & & \\
\hline \multirow{2}{*}{$\begin{array}{l}\text { Financial sector leverage } \\
\text { (loans/deposits, } t-1 \text { ) }\end{array}$} & & & -0.00139 & & \\
\hline & & & (0.00133) & & \\
\hline \multirow{2}{*}{\multicolumn{2}{|c|}{$\begin{array}{l}\text { Interconnectedness } \\
\text { (offshore deposits/domestic de) }\end{array}$}} & & & $0.0230 * *$ & \\
\hline & & & & (0.0110) & \\
\hline \multirow{2}{*}{$\begin{array}{l}\text { Interconnectedness } \\
\text { (non-resident loans/GDP, t-1) }\end{array}$} & & & & & $0.00704 * *$ \\
\hline & & & & & $(0.00338)$ \\
\hline \multirow[t]{2}{*}{ Const } & $2.504 * * *$ & $2.515^{* * *}$ & $2.857 * * *$ & $2.911 * * *$ & $3.068^{* * *}$ \\
\hline & $(0.341)$ & $(0.339)$ & $(0.351)$ & $(0.534)$ & $(0.340)$ \\
\hline$N$ & 53 & 53 & 53 & 36 & 37 \\
\hline $\mathrm{R}-\mathrm{sq}$ & 0.309 & 0.304 & 0.270 & 0.396 & 0.403 \\
\hline $\mathrm{F}$ & 5.566 & 5.559 & 3.672 & 6.960 & 6.861 \\
\hline$p$ & 0.000417 & 0.000421 & 0.00692 & 0.000202 & 0.000205 \\
\hline
\end{tabular}

Source: Authors' estimates.

Notes: Robust standard errors in parentheses. The symbols $* * *, * *$, and * indicate statistical significance at the 1 percent, 5 percent, and 10 percent levels, respectively.

Dependent variable is the log of direct fiscal costs in percent of GDP. Estimated coefficients $(\beta)$ reflect a loglinear relation; hence, a unit increase in the independent variable is associated with a $\left(e^{\beta}-1\right) \times 100$ percent change in the dependent variable. 
Table A1b. Basic Model: Conditional Correlations of Direct Fiscal Costs

\begin{tabular}{|c|c|c|c|c|}
\hline & (1) & (2) & (3) & (4) \\
\hline \multirow[t]{2}{*}{ Income per capita ( $t-1)$} & -0.00343 & -0.00307 & -0.00190 & -0.00214 \\
\hline & (0.00229) & $(0.00224)$ & (0.00217) & $(0.00241)$ \\
\hline \multirow[t]{2}{*}{ Public debt/GDP (t-1) } & -0.00109 & -0.00196 & -0.00574 & -0.00591 \\
\hline & (0.00517) & $(0.00505)$ & (0.00691) & (0.00349) \\
\hline \multirow[t]{2}{*}{ Current account/GDP (t-1) } & -0.0437 & $-0.0474 *$ & $-0.0674 * *$ & $-0.0558 *$ \\
\hline & $(0.0276)$ & (0.0274) & $(0.0255)$ & $(0.0281)$ \\
\hline \multirow[t]{2}{*}{ Banking supervision index } & $-0.320 * *$ & $-0.315^{*}$ & $-0.410 * *$ & $-0.520^{* * *}$ \\
\hline & $(0.157)$ & $(0.160)$ & (0.199) & (0.179) \\
\hline Deposit insurance coverage & $-0.00186 * *$ & $-0.00191 * *$ & $-0.00348^{* * *}$ & $-0.00279 * *$ \\
\hline (covered deposits/GDP per capita, t-1) & $(0.000899)$ & $(0.000906)$ & $(0.00125)$ & $(0.00132)$ \\
\hline Non-financial sector leverage & $0.00771 *$ & & & \\
\hline (private credit/GDP, $\mathrm{t}-1$ ) & $(0.00452)$ & & & \\
\hline Size of financial sector & & 0.00649 & & \\
\hline (assets/GDP, $\mathrm{t}-1$ ) & & $(0.00430)$ & & \\
\hline Interconnectedness & & & $0.0295 * * *$ & \\
\hline (offshore deposits/domestic deposits, t-1) & & & $(0.00971)$ & \\
\hline Interconnectedness & & & & $0.00666 *$ \\
\hline (non-resident loans/GDP, t-1) & & & & $(0.00348)$ \\
\hline Const & $2.457 * * *$ & $2.479 * * *$ & $3.141 * * *$ & $3.385^{* * *}$ \\
\hline $\mathrm{N}$ & 46 & 46 & 34 & 35 \\
\hline$R-s q$ & 0.373 & 0.361 & 0.554 & 0.519 \\
\hline $\mathrm{F}$ & 4.549 & 4.474 & 7.250 & 6.082 \\
\hline $\mathrm{p}$ & 0.00138 & 0.00155 & 0.000110 & 0.000360 \\
\hline
\end{tabular}

Source: Authors' estimates.

Notes: Robust standard errors in parentheses. The symbols $* * *, * *$, and $*$ indicate statistical significance at the 1 percent, 5 percent, and 10 percent levels, respectively.

Dependent variable is the log of direct fiscal costs in percent of GDP. Estimated coefficients $(\beta)$ reflect a loglinear relation; hence, a unit increase in the independent variable is associated with a $\left(e^{\beta}-1\right) \times 100$ percent change in the dependent variable. 


\section{Table A2. Extended Model: Conditional Correlations of Direct Fiscal Costs}

\begin{tabular}{|c|c|c|c|c|c|c|c|c|c|c|}
\hline & (1) & (2) & (3) & (4) & (5) & (6) & (7) & (8) & (9) & (10) \\
\hline Income per capita ( $\mathrm{t}-1)$ & $\begin{array}{c}-0.00320^{*} \\
(0.00178)\end{array}$ & $\begin{array}{c}-0.00312^{*} \\
(0.00180)\end{array}$ & $\begin{array}{c}-0.000626 \\
(0.00153)\end{array}$ & $\begin{array}{c}-0.00139 \\
(0.00213)\end{array}$ & $\begin{array}{c}-0.00213 \\
(0.00210)\end{array}$ & $\begin{array}{c}-0.00304 \\
(0.00181)\end{array}$ & $\begin{array}{c}-0.00286 \\
(0.00180)\end{array}$ & $\begin{array}{c}-0.000475 \\
(0.00145)\end{array}$ & $\begin{array}{c}0.00131 \\
(0.00222)\end{array}$ & $\begin{array}{c}-0.000301 \\
(0.00222)\end{array}$ \\
\hline Public debt/GDP (t-1) & $\begin{array}{c}-0.00363 \\
(0.00540)\end{array}$ & $\begin{array}{l}-0.00467 \\
(0.00543)\end{array}$ & $\begin{array}{r}-0.00478 \\
(0.00358)\end{array}$ & $\begin{array}{r}-0.00636 \\
(0.00780)\end{array}$ & $\begin{array}{c}-0.00504 \\
(0.00356)\end{array}$ & $\begin{array}{c}-0.00260 \\
(0.00422)\end{array}$ & $\begin{array}{c}-0.00383 \\
(0.00421)\end{array}$ & $\begin{array}{r}-0.00112 \\
(0.00365)\end{array}$ & $\begin{array}{c}-0.0126^{*} \\
(0.00639)\end{array}$ & $\begin{array}{c}-0.00389 \\
(0.00442)\end{array}$ \\
\hline Current account/GDP (t-1) & $\begin{array}{l}-0.0279 \\
(0.0255)\end{array}$ & $\begin{array}{l}-0.0311 \\
(0.0258)\end{array}$ & $\begin{array}{l}-0.0432 \\
(0.0274)\end{array}$ & $\begin{array}{l}-0.0499^{*} \\
(0.0267)\end{array}$ & $\begin{array}{l}-0.0413 \\
(0.0280)\end{array}$ & $\begin{array}{c}0.0218 \\
(0.0539)\end{array}$ & $\begin{array}{l}0.00422 \\
(0.0544)\end{array}$ & $\begin{array}{l}-0.0178 \\
(0.0533)\end{array}$ & $\begin{array}{c}0.0300 \\
(0.0675)\end{array}$ & $\begin{array}{l}-0.0276 \\
(0.0622)\end{array}$ \\
\hline Banking supervision index & $\begin{array}{c}-0.461^{* * *} \\
(0.128)\end{array}$ & $\begin{array}{c}-0.448^{* * *} \\
(0.124)\end{array}$ & $\begin{array}{c}-0.479 * * * \\
(0.132)\end{array}$ & $\begin{array}{c}-0.582^{* * *} \\
(0.203)\end{array}$ & $\begin{array}{c}-0.665^{* * *} \\
(0.170)\end{array}$ & $\begin{array}{l}-0.145 \\
(0.177)\end{array}$ & $\begin{array}{l}-0.121 \\
(0.172)\end{array}$ & $\begin{array}{l}-0.159 \\
(0.205)\end{array}$ & $\begin{array}{l}-0.472 \\
(0.315)\end{array}$ & $\begin{array}{l}-0.396 \\
(0.377)\end{array}$ \\
\hline $\begin{array}{l}\text { Non-financial sector leverage } \\
\text { (private credit/GDP, t-1) }\end{array}$ & $\begin{array}{l}0.00726 * \\
(0.00395)\end{array}$ & & & & & $\begin{array}{l}0.00853^{* *} \\
(0.00323)\end{array}$ & & & & \\
\hline $\begin{array}{l}\text { Size of financial sector } \\
\text { (assets/GDP, } t-1)\end{array}$ & & $\begin{array}{l}0.00636^{*} \\
(0.00336)\end{array}$ & & & & & $\begin{array}{l}0.00664 * * \\
(0.00268)\end{array}$ & & & \\
\hline $\begin{array}{l}\text { Financial sector leverage } \\
\text { (loans/deposits, t-1) }\end{array}$ & & & $\begin{array}{l}-0.00136 \\
(0.00141)\end{array}$ & & & & & $\begin{array}{l}0.000204 \\
(0.00187)\end{array}$ & & \\
\hline $\begin{array}{l}\text { Interconnectedness } \\
\text { (offshore deposits/domestic deposits, t-1) }\end{array}$ & & & & $\begin{array}{l}0.0288^{* * *} \\
(0.0103)\end{array}$ & & & & & $\begin{array}{l}0.00270 \\
(0.0122)\end{array}$ & \\
\hline $\begin{array}{l}\text { Interconnectedness } \\
\text { (non-resident loans/GDP, t-1) }\end{array}$ & & & & & $\begin{array}{c}0.00753^{* *} \\
(0.00278)\end{array}$ & & & & & $\begin{array}{c}0.00542 \\
(0.00459)\end{array}$ \\
\hline Bank guarantee (dummy) & $\begin{array}{l}0.380 \\
(0.310)\end{array}$ & $\begin{array}{l}0.388 \\
(0.307)\end{array}$ & $\begin{array}{l}0.625^{* *} \\
(0.271)\end{array}$ & $\begin{array}{l}0.743^{* *} \\
(0.355)\end{array}$ & $\begin{array}{l}0.615^{*} \\
(0.346)\end{array}$ & & & & & \\
\hline Forbearance (dummy) & & & & & & $\begin{array}{l}0.568 \\
(0.339)\end{array}$ & $\begin{array}{c}0.581 \\
(0.349)\end{array}$ & $\begin{array}{l}0.530 \\
(0.358)\end{array}$ & $\begin{array}{l}0.205 \\
(0.482)\end{array}$ & $\begin{array}{c}0.116 \\
(0.431)\end{array}$ \\
\hline Const & $\begin{array}{l}2.452^{* * *} \\
(0.347)\end{array}$ & $\begin{array}{c}2.461^{* * *} \\
(0.345)\end{array}$ & $\begin{array}{c}2.763^{* * *} \\
(0.346)\end{array}$ & $\begin{array}{c}2.533^{* * *} \\
(0.498)\end{array}$ & $\begin{array}{c}2.860^{* * *} \\
(0.315)\end{array}$ & $\begin{array}{c}2.175^{* * * *} \\
(0.424)\end{array}$ & $\begin{array}{c}2.162^{* * *} \\
(0.432)\end{array}$ & $\begin{array}{c}2.220^{* * *} \\
(0.467)\end{array}$ & $\begin{array}{c}3.549 * * * \\
(0.796)\end{array}$ & $\begin{array}{c}2.998 * * * \\
(0.573)\end{array}$ \\
\hline $\mathrm{N}$ & 53 & 53 & 53 & 36 & 37 & 35 & 35 & 35 & 18 & 19 \\
\hline$R-s q$ & 0.328 & 0.324 & 0.326 & 0.460 & 0.450 & 0.318 & 0.298 & 0.169 & 0.322 & 0.268 \\
\hline $\mathrm{F}$ & 6.662 & 6.652 & 6.581 & 5.165 & 7.595 & 2.410 & 2.650 & 1.433 & 2.188 & 1.415 \\
\hline $\mathrm{p}$ & 0.0000404 & 0.0000410 & 0.0000455 & 0.00102 & 0.0000514 & 0.0528 & 0.0366 & 0.237 & 0.123 & 0.286 \\
\hline
\end{tabular}

Notes: Robust standard errors in parentheses. The symbols ***, **, and * indicate statistical significance at the 1 percent, 5 percent, and 10 percent levels, respectively.

Dependent variable is the log of direct fiscal costs in percent of GDP. Estimated coefficients $(\beta)$ reflect a log-linear relation; hence, a unit increase in the independent variable is associated with a $\left(e^{\beta}-1\right) \times 100$ percent change in the dependent variable. 
Table A3. Extended Model: Conditional Correlations of Direct Fiscal Costs During Recent Crisis

\begin{tabular}{|c|c|c|c|c|}
\hline & (1) & (2) & (3) & (4) \\
\hline Income per capita (t-1) & $\begin{array}{l}-0.00369 * * \\
(0.00177)\end{array}$ & $\begin{array}{l}-0.00410^{* *} \\
(0.00179)\end{array}$ & $\begin{array}{r}-0.000869 \\
(0.00298)\end{array}$ & $\begin{array}{l}-0.00109 \\
(0.00263)\end{array}$ \\
\hline Public debt/GDP (t-1) & $\begin{array}{l}-0.00469 \\
(0.00544)\end{array}$ & $\begin{array}{l}-0.00662 \\
(0.00552)\end{array}$ & $\begin{array}{l}-0.00631 \\
(0.00781)\end{array}$ & $\begin{array}{l}-0.00417 \\
(0.00395)\end{array}$ \\
\hline Current account/GDP (t-1) & $\begin{array}{l}-0.0256 \\
(0.0275)\end{array}$ & $\begin{array}{l}-0.0299 \\
(0.0271)\end{array}$ & $\begin{array}{l}-0.0496 \\
(0.0304)\end{array}$ & $\begin{array}{l}-0.0439 \\
(0.0347)\end{array}$ \\
\hline Banking supervision index & $\begin{array}{l}-0.487 * * * \\
(0.143)\end{array}$ & $\begin{array}{l}-0.505^{* * *} \\
(0.144)\end{array}$ & $\begin{array}{l}-0.560^{* *} \\
(0.203)\end{array}$ & $\begin{array}{l}-0.588 * * * \\
(0.192)\end{array}$ \\
\hline $\begin{array}{l}\text { Banking supervision index } \\
\text { (recent crisis in AMs) }\end{array}$ & $\begin{array}{c}0.368 \\
(0.396)\end{array}$ & $\begin{array}{c}0.578 \\
(0.445)\end{array}$ & $\begin{array}{l}-0.0414 \\
(0.263)\end{array}$ & $\begin{array}{l}-0.0566 \\
(0.294)\end{array}$ \\
\hline $\begin{array}{l}\text { Non-financial sector leverage } \\
\text { (private credit/GDP, } t-1 \text { ) }\end{array}$ & $\begin{array}{c}0.0115 * * * \\
(0.00382)\end{array}$ & & & \\
\hline $\begin{array}{l}\text { Non-financial sector leverage } \\
\text { (recent crisis in AMs) }\end{array}$ & $\begin{array}{l}-0.00786 \\
(0.00867)\end{array}$ & & & \\
\hline $\begin{array}{l}\text { Size of financial sector } \\
\text { (assets/GDP, t-1) }\end{array}$ & & $\begin{array}{c}0.0104 * * * \\
(0.00305)\end{array}$ & & \\
\hline $\begin{array}{l}\text { Size of financial sector } \\
\text { (recent crisis in AMs) }\end{array}$ & & $\begin{array}{l}-0.00978 \\
(0.00874)\end{array}$ & & \\
\hline $\begin{array}{l}\text { Interconnectedness } \\
\text { (offshore deposits/domestic deposits, t-1) }\end{array}$ & & & $\begin{array}{c}0.0102 \\
(0.0122)\end{array}$ & \\
\hline $\begin{array}{l}\text { Interconnectedness } \\
\text { (recent crisis in AMs) }\end{array}$ & & & $\begin{array}{c}0.0203 \\
(0.0167)\end{array}$ & \\
\hline $\begin{array}{l}\text { Interconnectedness } \\
\text { (non-resident loans/GDP, t-1) }\end{array}$ & & & & $\begin{array}{l}0.00728 \\
(0.0174)\end{array}$ \\
\hline $\begin{array}{l}\text { Interconnectedness } \\
\text { (recent crisis in AMs) }\end{array}$ & & & & $\begin{array}{c}-0.0000684 \\
(0.0171)\end{array}$ \\
\hline Const & $\begin{array}{l}2.503 * * * \\
(0.352)\end{array}$ & $\begin{array}{l}2.570 * * * \\
(0.341)\end{array}$ & $\begin{array}{l}3.066 * * * \\
(0.566)\end{array}$ & $\begin{array}{l}3.022 * * * \\
(0.459)\end{array}$ \\
\hline$N$ & 53 & 53 & 36 & 37 \\
\hline R-sq & 0.321 & 0.325 & 0.406 & 0.404 \\
\hline $\mathrm{F}$ & 5.117 & 5.855 & 5.162 & 4.648 \\
\hline $\mathrm{p}$ & 0.000247 & 0.0000723 & 0.000733 & 0.00137 \\
\hline
\end{tabular}

Source: Authors' estimates.

Notes: Robust standard errors in parentheses. The symbols $* * *, * *$, and * indicate statistical significance at the 1 percent, 5 percent, and 10 percent levels, respectively.

Dependent variable is the log of direct fiscal costs in percent of GDP. Estimated coefficients $(\beta)$ reflect a loglinear relation; hence, a unit increase in the independent variable is associated with a $\left(e^{\beta}-1\right) \times 100$ percent change in the dependent variable. 
Table A4. Extended Model for Direct Fiscal Costs: Accounting for NPLs

\begin{tabular}{|c|c|c|c|c|}
\hline & (1) & (2) & (3) & (4) \\
\hline \multirow[t]{2}{*}{ Income per capita (t-1) } & -0.00167 & -0.00149 & -0.000324 & -0.00162 \\
\hline & $(0.00172)$ & $(0.00178)$ & $(0.00194)$ & $(0.00179)$ \\
\hline \multirow[t]{2}{*}{ Public debt/GDP (t-1) } & -0.00708 & -0.00780 & -0.00910 & -0.00492 \\
\hline & $(0.00595)$ & $(0.00599)$ & $(0.00805)$ & $(0.00385)$ \\
\hline \multirow[t]{2}{*}{ Current account/GDP (t-1) } & -0.0298 & -0.0326 & $-0.0475^{*}$ & -0.0418 \\
\hline & (0.0249) & $(0.0251)$ & $(0.0253)$ & (0.0269) \\
\hline \multirow[t]{2}{*}{ Banking supervision index } & $-0.345^{* *}$ & $-0.332 * *$ & -0.340 & $-0.449 * *$ \\
\hline & $(0.137)$ & $(0.137)$ & $(0.207)$ & $(0.197)$ \\
\hline Peak NPLs & $0.0238^{* *}$ & $0.0233^{* *}$ & $0.0296 *$ & $0.0236^{*}$ \\
\hline (\% of total loans) & $(0.0109)$ & $(0.0111)$ & $(0.0150)$ & (0.0141) \\
\hline Non-financial sector leverage & $0.00580 *$ & & & \\
\hline (private credit/GDP, t-1) & $(0.00355)$ & & & \\
\hline Size of financial sector & & 0.00455 & & \\
\hline (assets/GDP, t-1) & & $(0.00292)$ & & \\
\hline Interconnectedness & & & $0.0272^{* * *}$ & \\
\hline (offshore deposits/domestic deposits, t-1) & & & $(0.00889)$ & \\
\hline Interconnectedness & & & & $0.00724^{* * *}$ \\
\hline (non-resident loans/GDP, t-1) & & & & $(0.00246)$ \\
\hline \multirow[t]{2}{*}{ Bank guarantee (dummy) } & 0.370 & 0.390 & $0.737^{* *}$ & $0.645^{*}$ \\
\hline & (0.289) & $(0.285)$ & $(0.356)$ & $(0.332)$ \\
\hline \multirow[t]{2}{*}{ Const } & $1.899 * * *$ & $1.927 * * *$ & $1.537^{* *}$ & $1.942 * * *$ \\
\hline & $(0.428)$ & $(0.425)$ & $(0.647)$ & $(0.657)$ \\
\hline $\mathrm{N}$ & 53 & 53 & 36 & 37 \\
\hline R-sq & 0.379 & 0.372 & 0.517 & 0.491 \\
\hline $\mathrm{F}$ & 6.684 & 6.765 & 4.793 & 6.393 \\
\hline $\mathrm{p}$ & 0.0000194 & 0.0000171 & 0.00121 & 0.000135 \\
\hline
\end{tabular}

Source: Authors' estimates.

Notes: Robust standard errors in parentheses. The symbols $* * *, * *$, and * indicate statistical significance at the 1 percent, 5 percent, and 10 percent levels, respectively.

Dependent variable is the log of direct fiscal costs in percent of GDP. Estimated coefficients $(\beta)$ reflect a $\log$ linear relation; hence, a unit increase in the independent variable is associated to with a $\left(e^{\beta}-1\right) \times 100$ percent change in the dependent variable. NPLs = non-performing loans. 
Table A5. Extended Model for Direct Fiscal Costs: Generalized Methods of Moments and Reverse Causality

\begin{tabular}{|c|c|c|c|c|}
\hline Income per capita (t-1) & $\begin{array}{c}(1) \\
-0.00496 * * * \\
(0.00172)\end{array}$ & $\begin{array}{c}(2) \\
-0.00432^{* * *} \\
(0.00158)\end{array}$ & $\begin{array}{c}(3) \\
-0.000876 \\
(0.00135)\end{array}$ & $\begin{array}{c}(4) \\
-0.000720 \\
(0.00136)\end{array}$ \\
\hline Public debt/GDP (t-1) & $\begin{array}{c}0.00141 \\
(0.00403)\end{array}$ & $\begin{array}{l}0.000672 \\
(0.00426)\end{array}$ & $\begin{array}{l}-0.00901^{*} \\
(0.00505)\end{array}$ & $\begin{array}{l}-0.00405^{*} \\
(0.00239)\end{array}$ \\
\hline Current account/GDP (t-1) & $\begin{array}{l}-0.0270 \\
(0.0196)\end{array}$ & $\begin{array}{l}-0.0318 \\
(0.0215)\end{array}$ & $\begin{array}{l}-0.0343^{*} \\
(0.0179)\end{array}$ & $\begin{array}{l}-0.0358 \\
(0.0240)\end{array}$ \\
\hline Banking supervision index & $\begin{array}{l}-0.434 * * * \\
(0.117)\end{array}$ & $\begin{array}{l}-0.436 * * * \\
(0.108)\end{array}$ & $\begin{array}{l}-0.747 * * * \\
(0.152)\end{array}$ & $\begin{array}{l}-0.693^{* * *} \\
(0.135)\end{array}$ \\
\hline $\begin{array}{l}\text { Non-financial sector leverage } \\
\text { (private credit/GDP, t-1) }\end{array}$ & $\begin{array}{l}0.00964 * * * \\
(0.00337)\end{array}$ & & & \\
\hline $\begin{array}{l}\text { Size of financial sector } \\
\text { (assets/GDP, } t-1 \text { ) }\end{array}$ & & $\begin{array}{c}0.00791 * * * \\
(0.00268)\end{array}$ & & \\
\hline $\begin{array}{l}\text { Interconnectedness } \\
\text { (offshore deposits/domestic de। }\end{array}$ & & & $\begin{array}{l}0.0304 * * * \\
(0.00780)\end{array}$ & \\
\hline $\begin{array}{l}\text { Interconnectedness } \\
\text { (non-resident loans/GDP, t- } 1 \text { ) }\end{array}$ & & & & $\begin{array}{l}0.00605^{* *} \\
(0.00257)\end{array}$ \\
\hline Bank guarantee (dummy) & $\begin{array}{l}0.812 * * \\
(0.344)\end{array}$ & $\begin{array}{c}0.883 * * * \\
(0.323)\end{array}$ & $\begin{array}{l}1.189 * * * \\
(0.186)\end{array}$ & $\begin{array}{c}0.707 * * * \\
(0.265)\end{array}$ \\
\hline Const & $\begin{array}{l}1.968^{* * *} \\
(0.244)\end{array}$ & $\begin{array}{l}1.971 * * * \\
(0.263)\end{array}$ & $\begin{array}{l}2.758 * * * \\
(0.307)\end{array}$ & $\begin{array}{c}2.878 * * * \\
(0.215)\end{array}$ \\
\hline $\mathrm{N}$ & 54 & 54 & 36 & 37 \\
\hline$R-s q$ & 0.268 & 0.238 & 0.368 & 0.375 \\
\hline difference-in-Sargan test & $\begin{array}{c}0.464932 \\
0.4953\end{array}$ & $\begin{array}{c}0.566191 \\
0.4518\end{array}$ & $\begin{array}{c}0.001048 \\
0.9742\end{array}$ & $\begin{array}{c}0.016654 \\
0.8973\end{array}$ \\
\hline Hansen test & $\begin{array}{c}20.2667 \\
0.2608\end{array}$ & $\begin{array}{c}21.7032 \\
0.1964\end{array}$ & $\begin{array}{c}10.8068 \\
0.2892\end{array}$ & $\begin{array}{c}14.9401 \\
0.0926\end{array}$ \\
\hline
\end{tabular}

Source: Authors' estimates.

Notes: Robust standard errors in parentheses. The symbols ***,**, and * indicate statistical significance at the 1 percent, 5 percent, and 10 percent levels, respectively.

Dependent variable is the log of direct fiscal costs in percent of GDP. Estimated coefficients $(\beta)$ reflect a loglinear relation; hence, a unit increase in the independent variable is associated with a $\left(e^{\beta}-1\right) \times 100$ percent change in the dependent variable. 
Table A6. Basic Model: Conditional Correlations of Overall Fiscal Costs

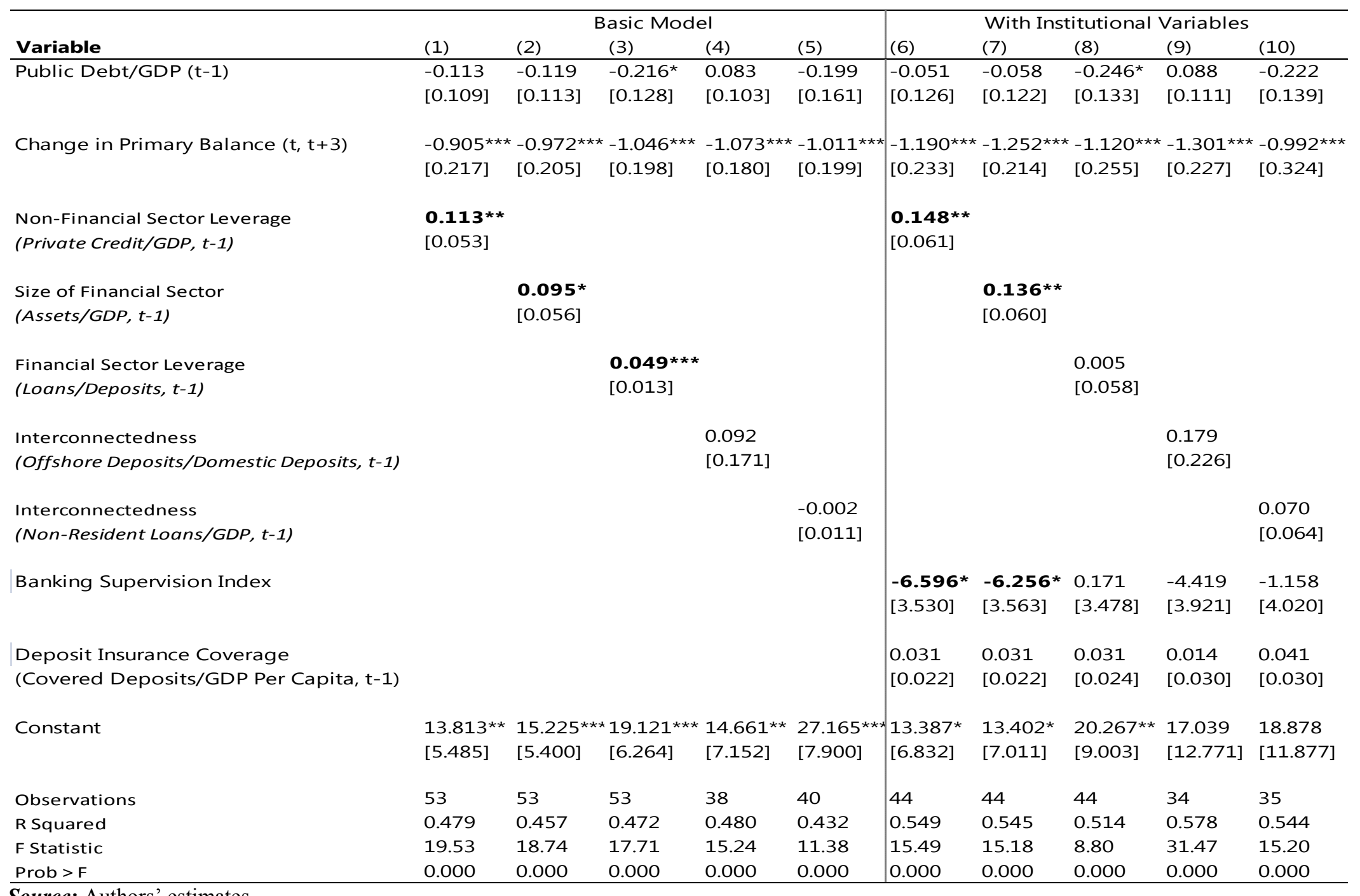

Source: Authors' estimates.

Notes: Robust standard errors in brackets. The symbols ***,**, and * indicate statistical significance at the 1 percent, 5 percent, and 10 percent levels, respectively.

Dependent variable is the change in public debt ratios over [ $\mathrm{T}-1 ; \mathrm{T}+4]$, where $\mathrm{T}$ is the starting year of the banking crisis 
Table A7. Extended Model: Conditional Correlations of Overall Fiscal Costs

\begin{tabular}{|c|c|c|c|c|c|c|c|c|c|c|c|}
\hline Variable & $(1)$ & $(2)$ & (3) & $(4)$ & $(5)$ & $(6)$ & $(7)$ & $(8)$ & $(9)$ & $(10)$ & $(11)$ \\
\hline \multirow[t]{2}{*}{ Public Debt/GDP (t-1) } & -0.124 & -0.110 & -0.109 & -0.124 & -0.116 & -0.113 & $-0.258^{\star *}$ & -0.218 & -0.192 & 0.052 & -0.232 \\
\hline & {$[0.106]$} & [0.113] & {$[0.111]$} & {$[0.106]$} & [0.116] & [0.114] & [0.127] & {$[0.133]$} & [0.115] & [0.104] & {$[0.161]$} \\
\hline \multirow[t]{2}{*}{ Change in Primary Balance $(t, t+3)$} & $-0.879 * \star *$ & $-0.899 * * \star$ & $-0.901^{\star \star \star}$ & -0.930 *** & $-0.965^{\star \star \star}$ & $-0.967^{\star \star \star}$ & $-0.904^{\star \star *}$ & $-1.033^{\star \star *}$ & $-1.010^{* \star *}$ & $-0.952^{\star \star *}$ & $-0.889 * * \star$ \\
\hline & [0.203] & {$[0.221]$} & [0.219] & {$[0.183]$} & {$[0.206]$} & {$[0.206]$} & [0.192] & [0.199] & [0.199] & {$[0.162]$} & [0.202] \\
\hline Non-Financial Sector Leverage & 0.072 & $0.111 *$ & $0.106 *$ & & & & & & & & \\
\hline (Private Credit/GDP, $t-1$ ) & {$[0.064]$} & [0.055] & {$[0.056]$} & & & & & & & & \\
\hline Size of Financial Sector & & & & 0.044 & 0.094 & 0.086 & & & & & \\
\hline (Assets/GDP, $t-1)$ & & & & {$[0.058]$} & [0.056] & {$[0.058]$} & & & & & \\
\hline Financial Sector Leverage & & & & & & & $0.037^{* *}$ & $0.052^{* * *}$ & $0.045^{* * *}$ & & \\
\hline (Loans/Deposits, $t-1$ ) & & & & & & & {$[0.017]$} & {$[0.014]$} & {$[0.015]$} & & \\
\hline Interconnectedness & & & & & & & & & & 0.120 & \\
\hline (Offshore Deposits/Domestic Deposits, $t$-1) & & & & & & & & & & [0.174] & \\
\hline Interconnectedness & & & & & & & & & & & -0.007 \\
\hline (Non-Resident Loans/GDP, $t-1$ ) & & & & & & & & & & & [0.010] \\
\hline \multirow[t]{2}{*}{ Bank Guarantee (Dummy) } & 9.223 & & & 11.224* & & & $12.532 * *$ & & & 11.993* & $13.260 *$ \\
\hline & [7.017] & & & [6.656] & & & [6.140] & & & {$[7.078]$} & [7.469] \\
\hline \multirow[t]{2}{*}{ Asset Purchases (Dummy) } & & 3.629 & & & 3.782 & & & 4.002 & & & \\
\hline & & {$[5.457]$} & & & [5.561] & & & [6.116] & & & \\
\hline \multirow[t]{2}{*}{ Bank Recapitalization (Dummy) } & & & 4.644 & & & 5.525 & & & 11.670 & & \\
\hline & & & [7.842] & & & [7.854] & & & [8.451] & & \\
\hline \multirow[t]{2}{*}{ Constant } & $12.529 * *$ & $12.097^{* *}$ & 10.292 & $13.546^{\star *}$ & $13.426^{\star \star}$ & 11.032 & $15.968^{* *}$ & $16.912^{\star *}$ & 8.969 & 7.757 & $20.291^{* *}$ \\
\hline & {$[5.755]$} & [5.494] & [8.100] & {$[5.730]$} & [5.539] & [8.034] & [6.447] & [7.167] & [8.919] & [6.226] & [8.159] \\
\hline Observations & 53 & 53 & 53 & 53 & 53 & 53 & 53 & 53 & 53 & 38 & 40 \\
\hline R Squared & 0.499 & 0.484 & 0.483 & 0.487 & 0.463 & 0.463 & 0.512 & 0.477 & 0.495 & 0.524 & 0.473 \\
\hline F Statistic & 17.03 & 16.39 & 15.14 & 16.98 & 16.16 & 14.61 & 16.24 & 15.27 & 14.44 & 14.91 & 10.01 \\
\hline Prob > F & 0.000 & 0.000 & 0.000 & 0.000 & 0.000 & 0.000 & 0.000 & 0.000 & 0.000 & 0.000 & 0.000 \\
\hline
\end{tabular}

Source: Authors' estimates.

Notes: Robust standard errors in brackets. The symbols ***,**, and * indicate statistical significance at the 1 percent, 5 percent, and 10 percent levels, respectively.

Dependent variable is the change in public debt ratios over [ $\mathrm{T}-1 ; \mathrm{T}+4]$, where $\mathrm{T}$ is the starting year of the banking crisis. 
Table A8. Extended Model for Overall Fiscal Costs: Accounting for NPLs and Losses Imposed on Depositors

\begin{tabular}{|c|c|c|c|c|c|c|c|c|c|c|c|c|c|c|c|c|c|c|c|c|c|c|c|c|c|}
\hline & (1) & (2) & (3) & (4) & (5) & (6) & (7) & (8) & (9) & (10) & (11) & (12) & (13) & (14) & (15) & (16) & (17) & (18) & (19) & (20) & (21) & (22) & (23) & (24) & (25) \\
\hline Public debt/GDP (change between $t-7$ and $t-1$ ) & $\left.\begin{array}{l}-0.103 \\
{[0.111]}\end{array}\right]$ & $\begin{array}{l}-0.117 \\
{[0.114]}\end{array}$ & $\begin{array}{l}-0.213 \\
0.1311\end{array}$ & $\begin{array}{l}0.124 \\
0.098]\end{array}$ & $\left.\begin{array}{r}-0.173 \\
{[0.172]}\end{array}\right]$ & \begin{tabular}{|c|c|}
-0.058 \\
{$[0.138]$}
\end{tabular} & $\begin{array}{l}-0.066 \\
0.133]\end{array}$ & $\begin{array}{l}-0.230^{*} \\
0.134]\end{array}$ & $\begin{array}{c}0.102 \\
{[0.100]}\end{array}$ & $\begin{array}{l}-0.204 \\
0.140]\end{array}$ & $\begin{array}{l}-0.117 \\
0.104]\end{array}$ & $\left.\begin{array}{l}-0.103 \\
{[0.112]}\end{array}\right]$ & $\begin{array}{l}-0.100 \\
{[0.113]}\end{array}$ & $\begin{array}{l}-0.125 \\
0.104]\end{array}$ & $\begin{array}{l}-0.117 \\
{[0.115]}\end{array}$ & $\left.\begin{array}{c}-0.112 \\
{[0.116]}\end{array}\right]$ & $\begin{array}{l}-0.263^{* *} \\
0.128\end{array}$ & $\begin{array}{l}-0.214 \\
{[0.134]}\end{array}$ & $\begin{array}{l}-0.188 \\
{[0.177]}\end{array}$ & $\begin{array}{c}0.089 \\
0.095]\end{array}$ & $\begin{array}{c}0.125 \\
{[0.099]}\end{array}$ & $\begin{array}{l}0.130 \\
0.098]\end{array}$ & $\begin{array}{l}-0.208 \\
{[0.171]}\end{array}$ & $\begin{array}{l}-0.171 \\
{[0.169]}\end{array}$ & $\begin{array}{l}-0.110 \\
{[0.137]}\end{array}$ \\
\hline Change in primary balance $(t, t+3)$ & $-1.036^{* * *}$ & $-1.098^{* * *}$ & $*-1.138^{* * *}$ & $-1.222^{* * *}$ & $-1.150^{* * * *}$ & $-1.240^{* * *}$ & $-1.304^{* * * *}$ & $-1.205^{* * *}$ & $-1.310^{* * *}$ & $-1.034^{* * *}$ & $-1.030^{* * *}$ & $*-1.034^{* * *}$ & $-1.042^{* * *}$ & $-1.068^{* * *}$ & $-1.096^{* * *}$ & $-1.102^{* * *}$ & $-1.036^{* * *}$ & $*^{-1.130 * * *}$ & $-1.139 * * *$ & $-1.107^{* * *}$ & $-1.222^{* * *}$ & & $-1.037^{* * * *}$ & $1.162^{* * *}$ & $*-1.121^{* * *}$ \\
\hline & $[0.21]]$ & {$[0.206]$} & {$[0.223]$} & {$[0.189]$} & {$[0.233]$} & {$[0.223]$} & {$[0.206]$} & {$[0.267]$} & {$[0.235]$} & {$[0.328]$} & {$[0.192]$} & {$[0.226]$} & {$[0.216]$} & {$[0.177]$} & {$[0.217]$} & {$[0.206]$} & {$[0.201]$} & {$[0.240]$} & {$[0.215]$} & {$[0.149]$} & {$[0.199]$} & {$[0.188]$} & {$[0.210]$} & {$[0.250]$} & {$[0.220]$} \\
\hline Peak NPL (\% total loans) & $\begin{array}{r}0.350 \\
0.2291\end{array}$ & 0.366 & 0.272 & 0.129 & $\begin{array}{r}0.145 \\
0.2251\end{array}$ & 0.219 & $\begin{array}{l}0.193 \\
0.276\end{array}$ & $\begin{array}{l}0.210 \\
0.219]\end{array}$ & $\begin{array}{l}-0.156 \\
10.2811\end{array}$ & $\begin{array}{r}0.040 \\
0.2599\end{array}$ & 0.358 & 0.345 & 0.351 & 0.367 & 0.362 & 0.366 & 0.312 & 0.258 & 0.285 & 0.222 & 0.126 & 0.121 & 0.215 & 0.182 & 0.123 \\
\hline Loss imposed on depositors (dummy) & -1.789 & -0.151 & 18 & 17.919 & 14.782 & 6.292 & 6.849 & 8.461 & 15.057 & 15.326 & 1.335 & -1.698 & -0.843 & 2.542 & -0.068 & 0.878 & 2.275 & -3.069 & -0.396 & 19.216 & 18.057 & $22.305^{*}$ & 16.791 & $\begin{array}{l}13.239] \\
13.467\end{array}$ & $\begin{array}{l}{[0.215]} \\
22.703^{* *}\end{array}$ \\
\hline $\begin{array}{l}\text { Non-financial sector leverage (private sector } \\
\text { credit/GDP, hange between } t-7 \text { and } t-1)\end{array}$ & $\begin{array}{l}{[11.882]} \\
0.113^{* * *}\end{array}$ & [11.850] & [11.483] & [14.724] & [13.240] & $\begin{array}{l}{[12.529]} \\
0.164^{* *}\end{array}$ & [12.359] & [11.830] & [14.456] & [12.058] & {$\left[\begin{array}{c}{[11.492]} \\
0.067\end{array}\right.$} & $\begin{array}{l}{[12.080]} \\
0.113^{* * *}\end{array}$ & $\begin{array}{l}{[12.427]} \\
0.107^{* *}\end{array}$ & [11.315] & {$[12.002]$} & [12.214] & {$[10.562]$} & {$[11.557]$} & [11.903] & [13.592] & [15.393] & [11.903] & [12.905] & [13.275] & [9.995] \\
\hline & {$[0.041]$} & & & & & {$[0.061]$} & & & & & {$[0.049]$} & {$[0.042]$} & {$[0.044]$} & & & & & & & & & & & & \\
\hline $\begin{array}{l}\text { Size of financial sector (Assets/GDP, change between } \\
t-7 \text { and } t-1 \text { ) }\end{array}$ & & $0.107^{* *}$ & & & & & $0.152^{* *}$ & & & & & & & 0.055 & $0.106^{* *}$ & $0.099^{* *}$ & & & & & & & & & \\
\hline & & {$[0.046]$} & & & & & {$[0.058]$} & & & & & & & {$[0.048]$} & {$[0.046]$} & {$[0.047]$} & & & & & & & & & \\
\hline $\begin{array}{l}\text { Financial sector leverage (loans/deposits, change } \\
\text { between } t-7 \text { and } t-1 \text { ) }\end{array}$ & & & $0.041^{* * *}$ & & & & & 0.024 & & & & & & & & & 0.022 & $0.043^{* *}$ & $0.035^{* *}$ & & & & & & \\
\hline & & & {$[0.015]$} & & & & & {$[0.062]$} & & & & & & & & & {$[0.017]$} & {$[0.017]$} & {$[0.016]$} & & & & & & \\
\hline $\begin{array}{l}\text { Interconnectedness (offshore deposits/domestic } \\
\text { deposits, change between } \mathrm{t}-\mathrm{7} \text { and } \mathrm{t}-1 \text { ) }\end{array}$ & & & & 0.110 & & & & & 0.152 & & & & & & & & & & & 0.161 & 0.109 & 0.096 & & & \\
\hline & & & & {$[0.144]$} & & & & & {$[0.235]$} & & & & & & & & & & & {$[0.139]$} & {$[0.148]$} & {$[0.144]$} & & & \\
\hline $\begin{array}{l}\text { Interconnectedness (nonresident loans/domestic } \\
\text { deposits, change between } t-7 \text { and } t-1 \text { ) }\end{array}$ & & & & & 0.001 & & & & & 0.065 & & & & & & & & & & & & & -0.004 & 0.000 & -0.001 \\
\hline & & & & & {$[0.010]$} & & & & & {$\left[\begin{array}{l}{[0.063]} \\
0.957\end{array}\right]$} & & & & & & & & & & & & & {$[0.009]$} & {$[0.010]$} & [0.008] \\
\hline Banking supervision index & & & & & & $\left.\begin{array}{|l}-5.341 \\
{[3.676]}\end{array}\right]$ & $\left.\begin{array}{l}-5.100 \\
{[3.746]}\end{array}\right]$ & $\left.\begin{array}{c}1.685 \\
{[3.546]}\end{array}\right]$ & $\left.\begin{array}{c}-4.397 \\
{[5.841]}\end{array}\right]$ & $\left.\begin{array}{c}0.957 \\
{[6.422]}\end{array}\right]$ & & & & & & & & & & & & & & & \\
\hline $\begin{array}{l}\text { Deposit insurance coverage (covered deposits/GDP } \\
\text { per capitat } t-1 \text { ) }\end{array}$ & & & & & & 0.031 & 0.032 & 0.032 & 0.014 & 0.044 & & & & & & & & & & & & & & & \\
\hline & & & & & & {$[0.022]$} & {$[0.022]$} & {$[0.026]$} & {$[0.028]$} & {$[0.029]$} & & & & & & & & & & & & & & & \\
\hline Bank guarantee (dummy) & & & & & & & & & & & \begin{tabular}{|l|l}
10.851 \\
{$[6.627]$}
\end{tabular} & & & $\begin{array}{l}12.221^{*} \\
{[6.367]}\end{array}$ & & & $\begin{array}{c}14.659 * * \\
{[5.862]}\end{array}$ & & & $\begin{array}{c}16.307 * * \\
{[6.663]}\end{array}$ & & & $\begin{array}{c}16.914^{* *} \\
{[7.166]}\end{array}$ & & \\
\hline Asset purchases (dummy) & & & & & & & & & & & & $\begin{array}{c}0.492 \\
{[5.404]}\end{array}$ & & & $\begin{array}{c}0.469 \\
{[5.620]}\end{array}$ & & & $\begin{array}{c}1.110 \\
{[6.507]}\end{array}$ & & & $\left.\begin{array}{c}0.340 \\
{[6.295]}\end{array}\right]$ & & & $\begin{array}{c}-3.813 \\
{[7.019]}\end{array}$ & \\
\hline Bank recapitalization (dummy) & & & & & & & & & & & & & $\begin{array}{c}4.458 \\
{[10.129]}\end{array}$ & & & $\begin{array}{c}5.393 \\
{[10.093]}\end{array}$ & & & $\begin{array}{c}12.317 \\
{[10.868]}\end{array}$ & & & $\begin{array}{c}14.039 \\
{[10.228]}\end{array}$ & & & $\begin{array}{l}23.176^{*} \\
{[12.734]}\end{array}$ \\
\hline Constant & $\begin{array}{l}6.995 \\
{[6.562]}\end{array}$ & $\begin{array}{c}7.235 \\
{[6.884]}\end{array}$ & $\begin{array}{c}15.478^{* *} \\
{[6.758]}\end{array}$ & $\begin{array}{l}7.243 \\
{[7.877]}\end{array}$ & $\begin{array}{r}20.477^{* *} \\
{[8.998]}\end{array}$ & \begin{tabular}{|c|}
5.363 \\
$9.207]$
\end{tabular} & $\begin{array}{l}5.986 \\
{[9.501]}\end{array}$ & $\begin{array}{c}9.288 \\
{[12.888]}\end{array}$ & $\begin{array}{l}17.755 \\
{[20.149]}\end{array}$ & $\begin{array}{c}11.203 \\
{[20.292]}\end{array}$ & $\begin{array}{c}4.603 \\
{[6.597]}\end{array}$ & $\begin{array}{c}6.850 \\
{[6.654]}\end{array}$ & $\begin{array}{c}3.316 \\
{[11.453]}\end{array}$ & $\begin{array}{c}4.614 \\
{[6.803]}\end{array}$ & $\begin{array}{l}7.100 \\
{[6.918]}\end{array}$ & $\begin{array}{c}2.789 \\
{[11.911]}\end{array}$ & $\begin{array}{l}10.625 \\
{[6.721]}\end{array}$ & $\begin{array}{c}15.055 * * \\
{[7.389]}\end{array}$ & $\begin{array}{c}4.085 \\
{[11.884]}\end{array}$ & $\begin{array}{l}-4.811 \\
{[7.200]}\end{array}$ & $\begin{array}{c}7.122 \\
{[7.640]}\end{array}$ & $\begin{array}{r}-5.316 \\
{[12.298]}\end{array}$ & $\begin{array}{l}9.554 \\
{[9.456]}\end{array}$ & $\begin{array}{c}21.770^{* *} \\
{[9.507]}\end{array}$ & $\begin{array}{r}-2.409 \\
{[14.540]}\end{array}$ \\
\hline & 5 & 52 & 52 & 38 & & 4 & 43 & 4 & 3 & 35 & 52 & 52 & & & 52 & & 52 & 52 & & 38 & 38 & 38 & 40 & 40 & 40 \\
\hline & 0.5 & & & & 481 & & 0.5 & 0.528 & & & 0.5 & 0.50 & 512 & 0.529 & 0. & 0.499 & 0.533 & 0. & 0.506 & 0.6 & 51 & 994 & 0.545 & 6 & 56 \\
\hline & & & & & & & & 0. & & & 0.4 & & & 0. & & 32 & 0.470 & & 40 & 0 & 6 & 0.515 & 0.462 & 92 & 75 \\
\hline & & & & & & & & & & & & & & & & & & & & & & & & & \\
\hline 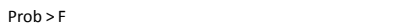 & 0.0000 & 0.0000 & 0.0000 & 0.0000 & 0.0001 & 0.0000 & 0.0000 & 0.0001 & 0.0000 & 0.0000 & 0.0000 & 0.0000 & 0.0000 & 0.0000 & 0.0000 & 0.0000 & 0.0000 & 0.0000 & 0.0000 & 0.0000 & 0.0000 & 0.0000 & 0.0000 & 0.0002 & 0.0001 \\
\hline
\end{tabular}

Source: Authors' estimates.

Notes: Robust standard errors in brackets. The symbols ***, ${ }^{* *}$, and $*$ indicate statistical significance at the 1 percent, 5 percent, and 10 percent levels, respectively.

Dependent variable is the change in public debt ratios over [ $\mathrm{T}-1 ; \mathrm{T}+4]$, where $\mathrm{T}$ is the starting year of the banking crisis. NPLs $=$ non-performing loans. 
Table A9. Extended Model for Overall Fiscal Costs: Generalized Method of Moments and Reverse Causality

\begin{tabular}{|c|c|c|c|c|c|c|c|c|c|c|c|c|c|c|c|}
\hline & (1) & (2) & (3) & (4) & (5) & (6) & (7) & (8) & (9) & (10) & (11) & (12) & (13) & (14) & (15) \\
\hline Public debt/GDP (t-1) & $\begin{array}{l}-0.122 \\
{[0.093]}\end{array}$ & $\begin{array}{l}-0.082 \\
{[0.108]}\end{array}$ & $\begin{array}{l}-0.077 \\
{[0.098]}\end{array}$ & $\begin{array}{l}-0.099 \\
{[0.082]}\end{array}$ & $\begin{array}{l}-0.071 \\
{[0.098]}\end{array}$ & $\begin{array}{l}-0.050 \\
{[0.085]}\end{array}$ & $\begin{array}{l}-0.291 * * * \\
{[0.090]}\end{array}$ & $\begin{array}{c}-0.197^{* *} \\
{[0.083]}\end{array}$ & $\begin{array}{l}-0.201^{* * *} \\
{[0.075]}\end{array}$ & $\begin{array}{c}0.097 \\
{[0.092]}\end{array}$ & $\begin{array}{l}0.179^{* *} \\
{[0.084]}\end{array}$ & $\begin{array}{l}0.183^{* *} \\
{[0.086]}\end{array}$ & $\begin{array}{l}-0.107 \\
{[0.099]}\end{array}$ & $\begin{array}{l}-0.112 \\
{[0.105]}\end{array}$ & $\begin{array}{l}-0.127 \\
{[0.104]}\end{array}$ \\
\hline Change in primary balance $(t, t+3)$ & $\begin{array}{c}-1.043^{* * *} \\
{[0.180]}\end{array}$ & $\begin{array}{l}-1.004^{* * *}- \\
{[0.196]}\end{array}$ & $\begin{array}{c}-1.048^{* * *} \\
{[0.188]}\end{array}$ & $\begin{array}{l}-1.105^{* * *} \\
{[0.138]}\end{array}$ & $\begin{array}{c}-1.035 * * * \\
{[0.161]}\end{array}$ & $\begin{array}{c}-1.130 * * * \\
{[0.129]}\end{array}$ & $\begin{array}{l}{ }^{k}-0.993^{* * *} \\
{[0.141]}\end{array}$ & $\begin{array}{c}-1.115^{* * *} \\
{[0.132]}\end{array}$ & $\begin{array}{l}*-1.132^{* * *} \\
\quad[0.093]\end{array}$ & $\begin{array}{l}-1.017 * * * \\
{[0.175]}\end{array}$ & $\begin{array}{c}-1.138 * * * \\
{[0.161]}\end{array}$ & $\begin{array}{c}-1.069^{* * *} \\
{[0.167]}\end{array}$ & $\begin{array}{l}-1.181^{* * *} \\
{[0.174]}\end{array}$ & $\begin{array}{l}-1.148^{* * *} \\
{[0.191]}\end{array}$ & $\begin{array}{c}-1.145^{* * *} \\
{[0.153]}\end{array}$ \\
\hline $\begin{array}{l}\text { Non-financial sector leverage (private } \\
\text { sector credit/GDP, } t-1 \text { ) }\end{array}$ & $\begin{array}{c}0.029 \\
{[0.069]}\end{array}$ & $\begin{array}{c}0.061 \\
{[0.047]}\end{array}$ & $\begin{array}{c}0.036 \\
{[0.041]}\end{array}$ & & & & & & & & & & & & \\
\hline Size of financial sector (Assets/GDP, $t-1$ ) & & & & $\begin{array}{c}0.011 \\
{[0.050]}\end{array}$ & $\begin{array}{l}0.064^{*} \\
{[0.037]}\end{array}$ & $\begin{array}{c}0.029 \\
{[0.036]}\end{array}$ & & & & & & & & & \\
\hline $\begin{array}{l}\text { Financial sector leverage (loans/deposits, } \\
\text { t-1) }\end{array}$ & & & & & & & -0.037 & 0.002 & -0.050 & & & & & & \\
\hline & & & & & & & {$[0.038]$} & [0.035] & {$[0.036]$} & & & & & & \\
\hline $\begin{array}{l}\text { Interconnectedness (offshore } \\
\text { deposits/domestic deposits, } \mathrm{t}-1 \text { ) }\end{array}$ & & & & & & & & & & 0.257 & 0.123 & 0.227 & & & \\
\hline & & & & & & & & & & [0.179] & {$[0.214]$} & [0.194] & & & \\
\hline $\begin{array}{l}\text { Interconnectedness (nonresident } \\
\text { loans/domestic deposits, } t-1 \text { ) }\end{array}$ & & & & & & & & & & & & & 0.001 & 0.009 & -0.012 \\
\hline & & & & & & & & & & & & & {$[0.039]$} & {$[0.043]$} & [0.043] \\
\hline Bank guarantee (dummy) & $\begin{array}{c}5.672 \\
{[8.571]}\end{array}$ & & & $\begin{array}{c}7.414 \\
{[7.373]}\end{array}$ & & & $\begin{array}{l}9.687^{* *} \\
{[4.793]}\end{array}$ & & & $\begin{array}{l}10.357 \\
{[7.243]}\end{array}$ & & & $\begin{array}{c}0.897 \\
{[6.131]}\end{array}$ & & \\
\hline Asset purchases (dummy) & & $\begin{array}{c}7.074 \\
{[4.557]}\end{array}$ & & & $\begin{array}{c}10.506^{* *} \\
{[4.699]}\end{array}$ & & & $\begin{array}{c}3.698 \\
{[4.339]}\end{array}$ & & & $\begin{array}{c}2.059 \\
{[4.942]}\end{array}$ & & & $\begin{array}{c}1.288 \\
{[5.436]}\end{array}$ & \\
\hline Bank recapitalization (dummy) & & & $\begin{array}{l}9.290^{* *} \\
{[4.629]}\end{array}$ & & & $\begin{array}{l}9.246^{*} \\
{[4.751]}\end{array}$ & & & $\begin{array}{c}13.908^{* * *} \\
{[3.423]}\end{array}$ & & & $\begin{array}{c}4.564 \\
{[7.987]}\end{array}$ & & & $\begin{array}{c}9.225 \\
{[7.439]}\end{array}$ \\
\hline Constant & $\begin{array}{c}16.345^{* * *} \\
{[3.224]}\end{array}$ & $\begin{array}{c}11.797^{* * *} \\
{[3.575]}\end{array}$ & $\begin{array}{l}9.055^{*} \\
{[5.072]}\end{array}$ & $\begin{array}{c}15.992^{* * *} \\
{[3.311]}\end{array}$ & $\begin{array}{c}9.669 * * * \\
{[3.621]}\end{array}$ & $\begin{array}{l}8.722^{*} \\
{[5.085]}\end{array}$ & $\begin{array}{c}28.785^{* * *} \\
{[5.994]}\end{array}$ & $\begin{array}{c}22.705^{* * *} \\
{[5.469]}\end{array}$ & $\begin{array}{c}* 18.341 * * * \\
{[5.962]}\end{array}$ & $\begin{array}{c}0.877 \\
{[6.062]}\end{array}$ & $\begin{array}{c}4.211 \\
{[5.019]}\end{array}$ & $\begin{array}{c}0.203 \\
{[8.171]}\end{array}$ & $\begin{array}{c}18.553^{* * *} \\
{[5.725]}\end{array}$ & $\begin{array}{c}18.121^{* * *} \\
{[5.369]}\end{array}$ & $\begin{array}{c}13.823^{* *} \\
{[6.038]}\end{array}$ \\
\hline Observations & 51 & 51 & 51 & 51 & 51 & 51 & 51 & 51 & 51 & 36 & 36 & 36 & 38 & 38 & 38 \\
\hline R-squared & 0.489 & 0.475 & 0.469 & 0.492 & 0.470 & 0.468 & 0.505 & 0.454 & 0.477 & 0.545 & 0.502 & 0.503 & 0.435 & 0.433 & 0.477 \\
\hline Adjusted R-squared & 0.444 & 0.430 & 0.423 & 0.447 & 0.424 & 0.422 & 0.461 & 0.406 & 0.432 & 0.487 & 0.438 & 0.439 & 0.366 & 0.364 & 0.414 \\
\hline Wald chi2 & 188.6 & 114.8 & 191.0 & 177.6 & 115.2 & 154.6 & 201.0 & 161.6 & 350.5 & 180.1 & 139.3 & 158.7 & 120.6 & 117.0 & 132.4 \\
\hline Prob > chi 2 & 0.0000 & 0.0000 & 0.0000 & 0.0000 & 0.0000 & 0.0000 & 0.0000 & 0.0000 & 0.0000 & 0.0000 & 0.0000 & 0.0000 & 0.0000 & 0.0000 & 0.0000 \\
\hline
\end{tabular}

Source: Authors' estimates.

Notes: Robust standard errors in brackets. The symbols ***,**, and * indicate statistical significance at the 1 percent, 5 percent, and 10 percent levels, respectively.

Dependent variable is the change in public debt ratios over [T-1; T+4], where $\mathrm{T}$ is the starting year of the banking crisis. GMM $=$ Generalized Method of Moments. 
Table A10. Data and Data Sources

\begin{tabular}{|c|c|c|}
\hline Name & Description & Source \\
\hline Direct fiscal costs & Direct fiscal costs as a share of GDP & Laeven and Valencia (2013) \\
\hline Income per capita & GDP per capita & WEO \\
\hline $\begin{array}{l}\text { Public debt and overall } \\
\text { fiscal costs }\end{array}$ & Public debt as a share of GDP & $\begin{array}{l}\text { Abbas and others }(2010) \\
\text { spliced with general } \\
\text { government gross debt/GDP } \\
\text { from Mauro and others } \\
\text { (2013) }\end{array}$ \\
\hline Current account balance & $\begin{array}{l}\text { Current account balance as a share of } \\
\text { GDP }\end{array}$ & WEO \\
\hline Banking sector supervision & Banking sector supervision index & Abiad and others (2008) \\
\hline $\begin{array}{l}\text { Deposit insurance } \\
\text { coverage }\end{array}$ & $\begin{array}{l}\text { Deposit insurance coverage as a share } \\
\text { of GDP per capita }\end{array}$ & Laeven and Valencia (2013) \\
\hline Peak NPLs & $\begin{array}{l}\text { Peak non-performing loans (NPL) as a } \\
\text { share of total loans }\end{array}$ & Laeven and Valencia (2013) \\
\hline Financial sector leverage & $\begin{array}{l}\text { Private credit by deposit money banks } \\
\text { as a share of demand, time and saving } \\
\text { deposits in deposit money banks. }\end{array}$ & World Bank (2012) \\
\hline Size of financial sector & $\begin{array}{l}\text { Claims on domestic real nonfinancial } \\
\text { sector by deposit money banks as a } \\
\text { share of GDP }\end{array}$ & World Bank (2012) \\
\hline $\begin{array}{l}\text { Non-financial sector } \\
\text { leverage }\end{array}$ & $\begin{array}{l}\text { Private credit by deposit money banks } \\
\text { as a share of GDP }\end{array}$ & World Bank (2012) \\
\hline Interconnectedness 1 & $\begin{array}{l}\text { Offshore bank loans (amount } \\
\text { outstanding) as a share of GDP }\end{array}$ & World Bank (2012) \\
\hline Interconnectedness 2 & $\begin{array}{l}\text { Offshore bank deposits relative as a } \\
\text { share of domestic deposits }\end{array}$ & World Bank (2012) \\
\hline Policy response variables & $\begin{array}{l}\text { Bank guarantee and forbearance } \\
\text { dummies, asset purchases, bank } \\
\text { recapitalization, and losses imposed on } \\
\text { depositors }\end{array}$ & Laeven and Valencia (2013) \\
\hline
\end{tabular}


Table A11. Systemic Banking Crises and Recent Borderline Crisis Episodes

\begin{tabular}{|c|c|c|}
\hline Argentina & 1980, 1989, 1995, 2001 Korea & 1997 \\
\hline Austria & 2008 Latvia & 1995,2008 \\
\hline Belgium & 2008 Lithuania & 1995 \\
\hline Bolivia & 1994 Luxembourg & 2008 \\
\hline Brazil & 1990, 1994 Malaysia & 1997 \\
\hline Bulgaria & 1996 Mexico & 1994 \\
\hline Chile & 1981 Mongolia & 2008 \\
\hline Colombia & 1982, 1998 Netherlands & 2008 \\
\hline Côte d'Ivoire & 1988 Nicaragua & 2000 \\
\hline Croatia & 1998 Nigeria & 2009 \\
\hline Czech Republic & 1996 Norway & 1991 \\
\hline Denmark & 2008 Paraguay & 1995 \\
\hline Dominican Rep & 2003 Philippines & 1997 \\
\hline Ecuador & 1998 Portugal & 2008 \\
\hline Estonia & 1992 Russia & 1998,2008 \\
\hline Finland & 1991 Slovenia & 2008 \\
\hline France & 2008 Spain & 2008 \\
\hline Germany & 2008 Sri Lanka & 1989 \\
\hline Ghana & 1982 Sweden & 1991,2008 \\
\hline Greece & 2008 Switzerland & 2008 \\
\hline Hungary & 2008 Thailand & 1997 \\
\hline Iceland & 2008 Turkey & 2000 \\
\hline Indonesia & 1997 Ukraine & 1998,2008 \\
\hline Ireland & 2008 United Kingdom & 2007 \\
\hline Italy & 2008 United States & 2007 \\
\hline Jamaica & 1996 Uruguay & 2002 \\
\hline Japan & 1997 Venezuela & 1994 \\
\hline Kazakhstan & 2008 Vietnam & 1997 \\
\hline
\end{tabular}

Source: Laeven and Valencia (2013). 


\section{REFERENCES}

Abbas, S.M.A., N. Belhocine, A. El-Ganainy, and M. Horton (2011), "Historical Patterns and Dynamics of Public Debt_Evidence From a New Database," IMF Economic Review, 59(4): 717-42.

Abiad, A., E. Detragiache, and T. Tressel (2008), "A New Database of Financial Reforms," IMF Working Paper, 08/266.

Allen, F. and D. Gale (2003), "Liquidity, Asset Prices and Systemic Risk," Bank for International Settlements, Proceedings of the Third Joint Central Bank Research Conference.

Boissay, F., Collard, F., and F. Smets (2013), “Booms and Systemic Banking Crises,” ECB Working Paper Series, 1514.

Čihák M., R. Scuzzarella, and S. Munoz (2011), "The Bright and the Dark Side of CrossBorder Banking Linkages," IMF Working Paper 11/186.

Claessens, S., D. Klingebiel, and L. Laeven (2005), "Crisis Resolution, Policies, and Institutions: Empirical Evidence," in Patrick Honohan and Luc Laeven, Systemic Financial Crises: Containment and Resolution (Cambridge University Press).

Claessens, S., C. Pazarbasioglu, L. Laeven, M. Dobler, F. Valencia, O. Nedelescu, and K. Seal (2011), "Crisis Management and Resolution: Early Lessons from the Financial Crisis," IMF Staff Discussion Note, 11/05.

Demirgüç-Kunt, A. and H. Huizinga (2004), "Market Discipline and Deposit Insurance," Journal of Monetary Economics, 51, 375-99.

Demirgüç-Kunt, A. and E. Detragiache (1998), "The Determinants of Banking Crises in Developing and Developed Countries," IMF Staff Papers, 45: 81-109.

Deutsche Bank (2013), "Financial Crises: Past and Present," Global Economic Perspectives, Deutsche Bank Market Research.

Djankov, S., C. McLiesh, and A. Shleifer (2007), "Private Credit in 129 Countries" Journal of Financial Economics, 84 (May): 299-329.

Escolano, J., A. Shabunina, and J. Woo (2011), “The Puzzle of Persistently Negative Interest Rate-Growth Differentials; Financial Repression or Income Catch-Up?," IMF Working Paper, 11/260.

European Commission (2009), "The fiscal Costs of Financial Crises: Past Evidence and Implications for Today's Crisis," Public Finances in EMU. 
Frydl, E. (1999), “The Length and Cost of Banking Crises,” IMF Working Paper, 99/30.

Frydl, E. and M. Quintyn (2000), "The Benefits and Costs of Intervening in Banking Crises," IMF Working Paper, 00/147.

Gourinchas, P. and M. Obstfeld (2012), "Stories of the Twentieth Century for the TwentyFirst," American Economic Journal: Macroeconomics, 4(1): 226-65.

Hoggarth, G., R. Reis, and V. Saporta (2002), "Output Costs of Banking System Instability: Some Empirical Evidence," Journal of Banking and Finance, 26: 825-55.

Honohan, P. and D. Klingebiel (2003), "The Fiscal Cost Implications of an Accommodating Approach to Banking Crises,” Journal of Banking and Finance, 27: 1539-60.

Inter-American Development Bank (2005), "Unlocking Credit. The Quest for Deep and Stable Bank Lending," Economic and Social Progress Report.

International Monetary Fund (1998), "Financial Crises: Characteristics and Indicators of Vulnerability," World Economic Outlook.

(2003), “Managing Systemic Banking Crises,” Occasional Paper 224.

(2009), "The State of Public Finances: Outlook and Medium-Term Policies after the 2008 Crisis," Companion Paper.

(2011), "Towards Operationalizing Macroprudential Policies: When to Act?," September Global Financial Stability Report.

(2015), "From Banking to Sovereign Stress: Implications for Public Debt," Policy Paper.

Kalemli-Ozcan, S., B. Sorensen and S. Yesiltas (2012), "Leverage across Firms, Banks and Countries," Journal of International Economics, 88(22): 284-298.

Kaminsky, G. and C.M. Reinhart (1999), "The Twin Crises: The Causes of Banking and Balance-of-Payments Problems," American Economic Review, 89(3): 473-500.

Laeven, L. and F. Valencia (2008), “Systemic Banking Crises: A New Database,” IMF Working Paper, 08/224.

(2010), "Resolution of Banking Crises: The Good, the Bad, and the Ugly," IMF Working Paper, 10/44.

(2012), "Systemic Banking Crises Database: An Update," IMF Working Paper, $12 / 163$. 
(2013), “Systemic Banking Crises Database," IMF Economic Review, 61(2).

Lane, P. (2011), “The Irish Crisis,” IIIS Discussion Paper, 356.

Mauro, P., R. Romeu, A. Binder, and A. Zaman (2013), “A Modern History of Fiscal Prudence and Profligacy," IMF Working Paper, 13/05.

Reinhart, C. M. and K. S. Rogoff (2008), "Banking Crises: An Equal Opportunity Menace," NBER Working Paper, 14587. (2013), "Banking Crises: An Equal Opportunity Menace," Journal of Banking \& Finance, 37(11): 4557-73.

World Bank (2012), "Financial Structure Dataset," September: siteresources.worldbank.org/.../FinStructure_2012_September_Update2x. 